University of South Florida

DIGITAL COMMONS

Digital Commons @ University of

@ UNIVERSITY OF SOUTH FLORIDA

South Florida

$1-1-2015$

\title{
2015 Accountability Report USF St. Petersburg
}

USF

Follow this and additional works at: https://digitalcommons.usf.edu/usf_accountability_reports

\section{Scholar Commons Citation}

USF, "2015 Accountability Report USF St. Petersburg" (2015). USF Accountability Reports. 50.

https://digitalcommons.usf.edu/usf_accountability_reports/50

This Article is brought to you for free and open access by the USF Archives at Digital Commons @ University of South Florida. It has been accepted for inclusion in USF Accountability Reports by an authorized administrator of Digital Commons @ University of South Florida. For more information, please contact digitalcommons@usf.edu. 


\section{4-15}

\section{Annual Accountability Report}

\section{UNIVERSITY OF SOUTH FLORIDA SAINT PETERSBURG}

BOT APPROVED 3/3/2016

STATE UNIVERSITY SYSTEM of FLORIDA Board of Governors 


\section{TABLE OF CONTENTS}

\section{EXECUTIVE SUMMARY}

DASHBOARD

KEY ACHIEVEMENTS

NARRATIVE p. 2

p. 5

p. 6

\section{DATA TABLES}

SECTION 1. FINANCIAL RESOURCES p. 12

SECTION 2. PERSONNEL

p. 16

SECTION 3. ENROLLMENT

p. 17

SECTION 4. UNDERGRADUATE EDUCATION

p. 22

SECTION 5. GRADUATE EDUCATION

p. 30

SECTION 6. RESEARCH \& ECONOMIC DEVELOPMENT

p. 32 


\section{Dashboard}

\begin{tabular}{|c|c|c|c|c|c|c|c|c|}
\hline $\begin{array}{l}\text { Headcount } \\
\text { Enrollments }\end{array}$ & $\begin{array}{c}\text { Fall } \\
2014\end{array}$ & $\begin{array}{c}\% \\
\text { Total }\end{array}$ & $\begin{array}{l}\text { 2013-2014 } \\
\text { \% Change }\end{array}$ & \multicolumn{3}{|c|}{ Degree Programs Offered } & \multicolumn{2}{|c|}{2015 Carnegie Classifications } \\
\hline TOTAL & 4,596 & $100 \%$ & $-3 \%$ & \multicolumn{2}{|c|}{ TOTAL (as of Sprina 2015) } & 39 & \multirow{2}{*}{ Basic: } & \multirow{2}{*}{$\begin{array}{l}\text { Master's Colleges \& } \\
\text { Universities: Medium }\end{array}$} \\
\hline White & 3,176 & $69 \%$ & $-5 \%$ & \multicolumn{2}{|l|}{ Baccalaureate } & 26 & & \\
\hline Hispanic & 649 & $14 \%$ & $3 \%$ & \multicolumn{2}{|c|}{ Master's \& Specialist's } & 13 & \multirow{2}{*}{$\begin{array}{c}\text { Undergraduate } \\
\text { Instructional Program: }\end{array}$} & \multirow{2}{*}{$\begin{array}{l}\text { Balanced arts \& } \\
\text { sciences/professions, } \\
\text { some graduate }\end{array}$} \\
\hline Black & 334 & $7 \%$ & $-3 \%$ & \multicolumn{2}{|c|}{ Research Doctorate } & 0 & & \\
\hline Other & 437 & $10 \%$ & $2 \%$ & \multicolumn{2}{|c|}{ Professional Doctorate } & 0 & \multirow{2}{*}{$\begin{array}{c}\text { Graduate } \\
\text { Instructional Program: }\end{array}$} & \multirow{2}{*}{$\begin{array}{l}\text { Post-baccalaureate: } \\
\text { Education-dominant, with } \\
\text { Arts \& Sciences }\end{array}$} \\
\hline Full-Time & 2,703 & $59 \%$ & $-3 \%$ & \multirow{2}{*}{$\begin{array}{l}\text { Faculty } \\
\text { (Fall 2014) }\end{array}$} & \multirow{2}{*}{$\begin{array}{l}\text { Full- } \\
\text { Time }\end{array}$} & \multirow{2}{*}{$\begin{array}{l}\text { Part- } \\
\text { Time }\end{array}$} & & \\
\hline Part-Time & 1,893 & $41 \%$ & $-3 \%$ & & & & \multirow{2}{*}{ Size and Setting: } & \multirow{2}{*}{$\begin{array}{l}\text { Four-year, medium, } \\
\text { primarily nonresidential }\end{array}$} \\
\hline Undergraduate & 3,835 & $83 \%$ & $-3 \%$ & TOTAL & 128 & 143 & & \\
\hline Graduate & 530 & $12 \%$ & $-4 \%$ & Tenure \& Ten. Track & 90 & 3 & \multirow{2}{*}{$\begin{array}{l}\text { Community } \\
\text { Engagement: }\end{array}$} & \multirow{2}{*}{ Yes } \\
\hline Unclassified & 231 & $5 \%$ & $-3 \%$ & Non-Tenured Faculty & 38 & 139 & & \\
\hline
\end{tabular}

\section{DEGREE PRODUCTIVITY AND PROGRAM EFFICIENCY}
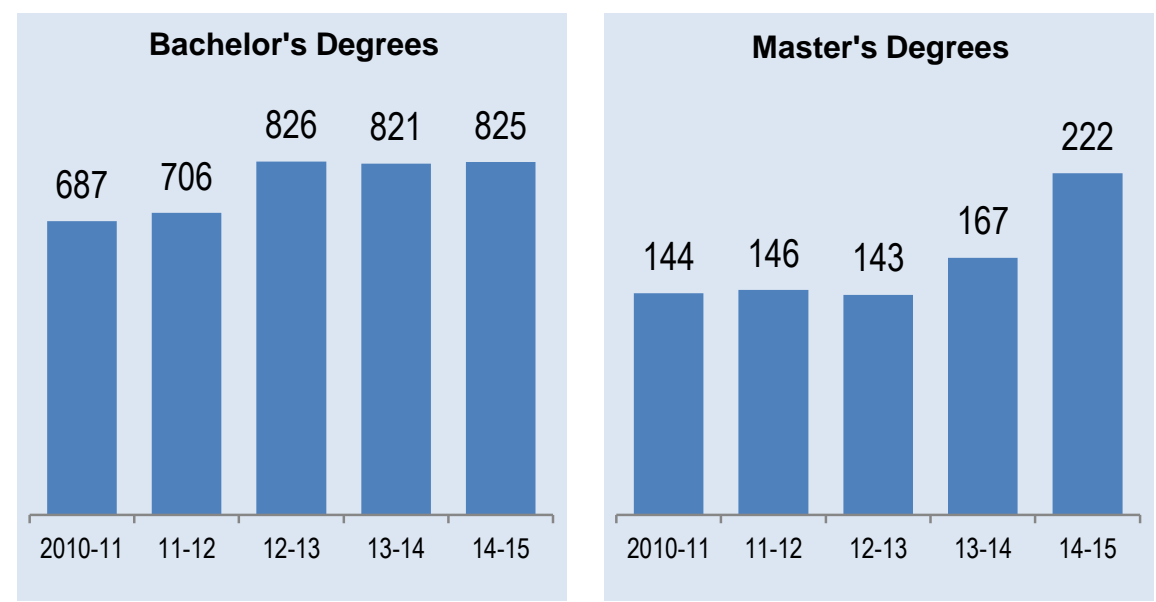

\section{Graduation Rates by Student Type}

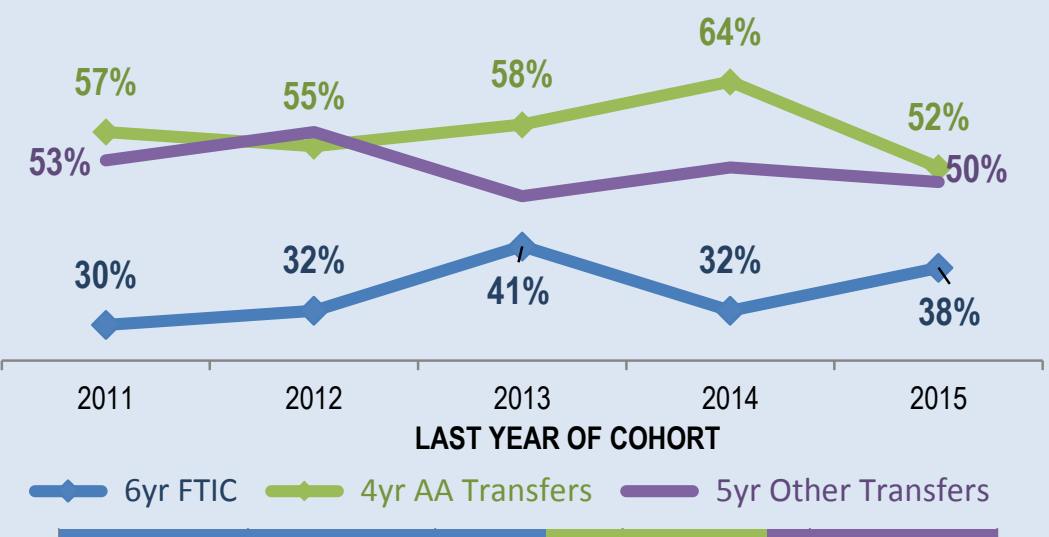

PROPORTION OF STUDENTS IN COHORTS ENDING IN 2015

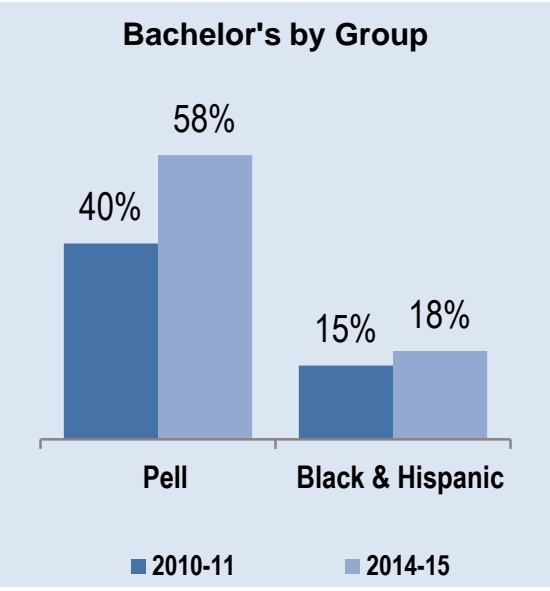

Bachelor's Degrees
Without Excess Hours

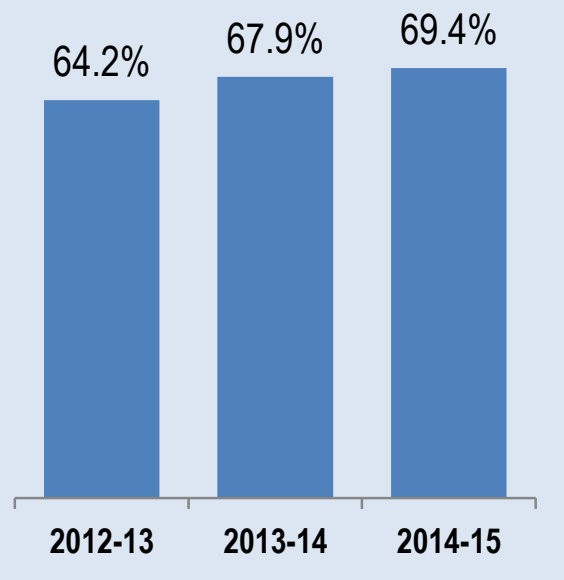




\section{Dashboard}

\section{DEGREES AWARDED IN PROGRAMS OF STRATEGIC EMPHASIS (PSE)}
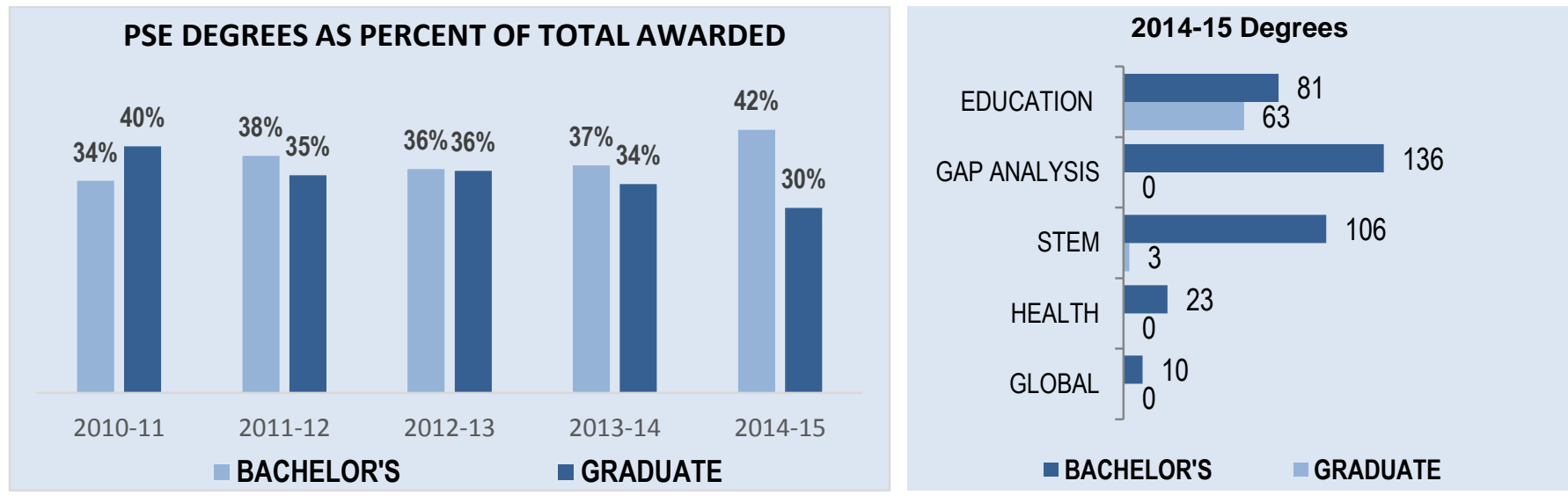

\section{RESEARCH AND COMMERCIALIZATION ACTIVITY}

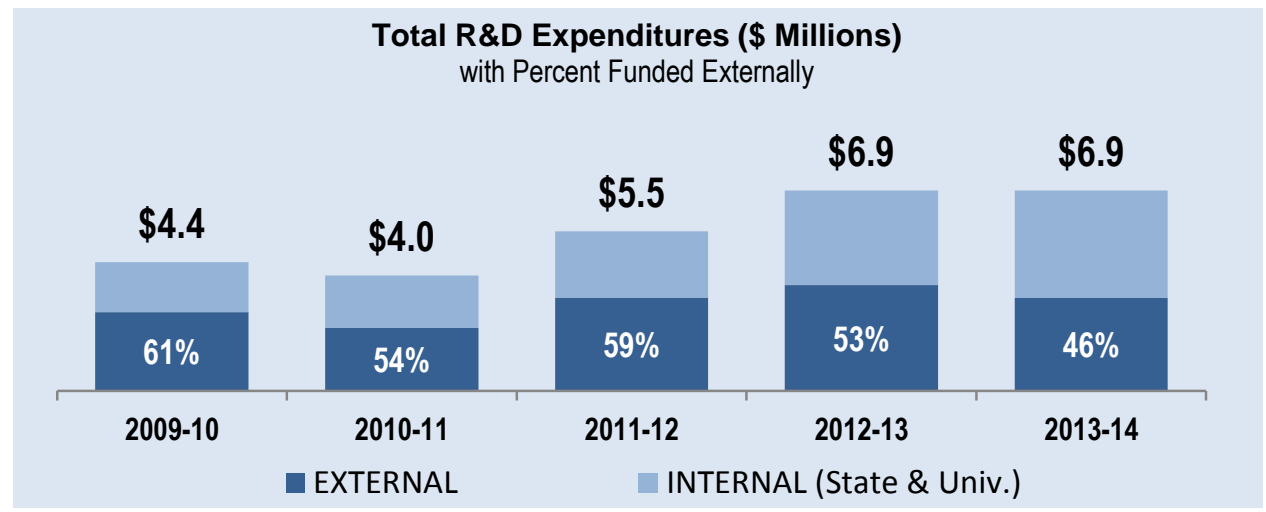

RESOURCES

\section{ACTUAL FUNDING PER FTE}

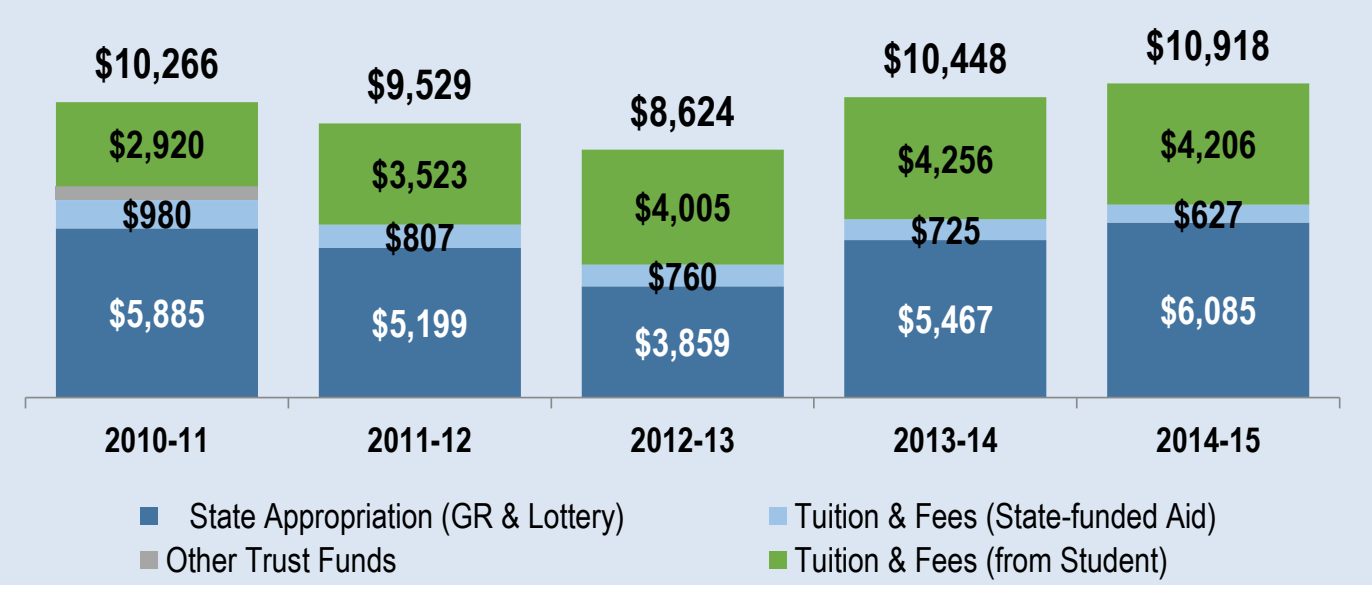

Note: Tuition and Fee revenues include tuition, tuition differential fee and $E \& G$ fees (i.e., application, late registration, and library fees/fines) based on the actual amount collected (not budget authority) by universities as reported in their Operating Budget 625 reports. Other local fees that do not support E\&G activities are not included here. Please note that a portion of the Tuition \& Fees is supported by federal SFA programs (ie, Pell grants). State-funded Student Financial Aid amounts include the 11 SFA programs that OSFA reports annually. State Appropriations includes General Revenues, Lottery and Other Trust funds (i.e., Federal Stimulus for 2009-10 and 2010-11 only) that are directly appropriated to the university as reported in Final Amendment Package. Student FTE are actual and based on the standard IPEDS definition of FTE (equal to 30 credit hours for undergraduates and 24 for graduates). This data does not include funds or FTE from special units (i.e., IFAS, Health-Science Centers or Medical Schools). Not adjusted for inflation. 


\section{Dashboard}

\section{POST-GRADUATION METRICS}

\section{Percent of Bachelor's Graduates Employed or Continuing their Education One Year After Graduation}

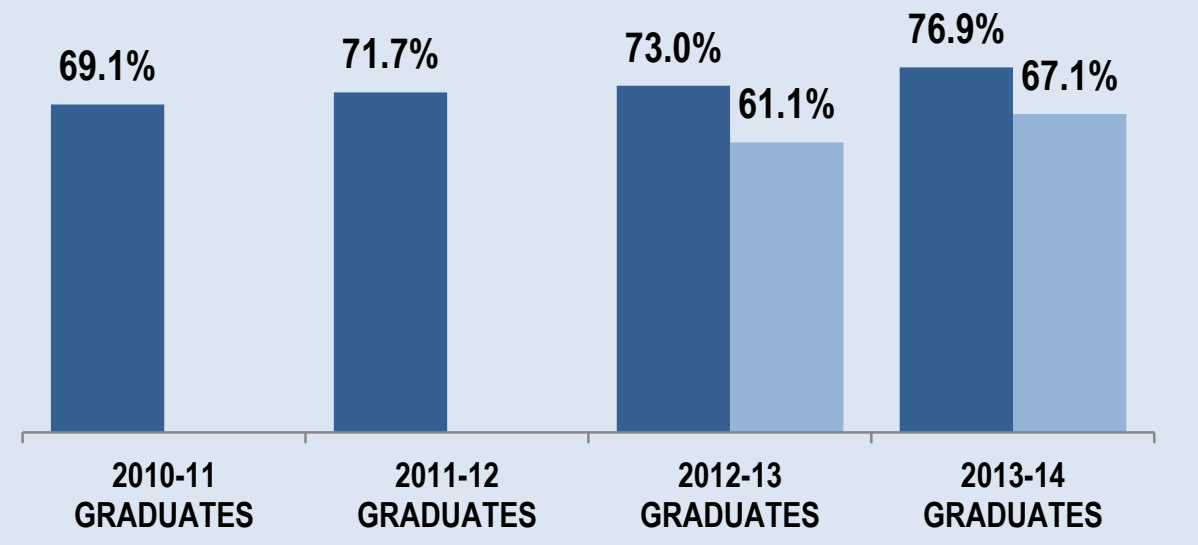

- Enrolled or Employed (Full-time) $\quad$ Enrolled or Employed (Earning \$25,000+)
Notes: Percentages are based on the number of recent baccalaureate graduates who are either employed full-time or continuing their education in the U.S. (based on the National Student Clearinghouse data). Full-time employment is based on those who earned more than a full-time (40hrs a week) worker making minimum wage. Due to limitations in the data, the continuing enrollment data includes any enrollment the following year regardless of whether the enrollment was post-baccalaureate or not. BOG staff 'found' $92 \%$ of USFSt.Pete's 2013-14 bachelor's recipients. See Table 40 within this report for additional information about this metric.

Notes: Wage data is based on Florida's annualized Unemployment Insurance (UI) wage data for those graduates who earned more than a full-time employee making minimum wage in the fiscal quarter a full year after graduation. This Ul wage data does not include individuals who are self-employed, employed out of state, employed by the military or federal government, or those without a valid social security number. In 2013-14, these data accounted for $62 \%$ of the total graduating class. This wage data includes graduates who were employed full-time (regardless of their continuing enrollment). Wages are provided for 5th, 25th, 50th, 75th and 95th percentiles. Median wages are identified by bolded values. The interquartile range (shown in italics) represents $50 \%$ of the wage data. Wages rounded to nearest hundreds. 


\section{Key Achievements (2014-2015)}

Limit to one page. Please don't include achievements reported last year.

\section{STUDENT AWARDS/ACHIEVEMENTS}

1. Political Science junior Tyler Lewis interned at the White House during the Spring 2015 semester, joining students from Columbia, Harvard and Cornell, among others.

2. Five Entrepreneurship students combined their talents to win 1st and 3rd prizes at the Global Entrepreneurship Week, Startup Weekend Tampa Bay.

3. The work of undergraduate student Lauren Dellert, "Effects of Beach Renourishment and Clutch Relocation on the Success of the Loggerhead Sea Turtle (Caretta Caretta) Eggs and Hatchlings," was published in The Journal of Herpetology.

4. Biology students Bethany Porcelli and Alexa Brandstetter were chosen to lead the national PreVeterinary Medicine Association.

5. Several USFSP Graphic Design seniors received Gold awards at the American Advertising Federation's regional ADDY Awards ceremony in Spring 2015. The students were recognized by the Federation for professional-level work.

\section{FACULTY AWARDS/ACHIEVEMENTS}

1. The Anthropology team of Drs. Kathryn and John Arthur continued NSF-funded research to determine the age of a skeleton the team had unearthed in Ethiopia in 2012. They worked closely with geneticists at Cambridge University on a DNA analysis that would lead to a major discovery in the fall of 2015.

2. Seven faculty either traveled as Fulbright Scholars or were awaiting assignments.

3. Dr. V. Mark Durand received the 2015 American Psychological Association's Jacobson Award for Critical Thinking.

4. For a second time, Rome Prize recipient Dr. Sheramy Bundrick was chosen to be one of the Archaeological Institute of America's national lecturers.

\section{PROGRAM AWARDS/ACHIEVEMENTS}

1. USFSP's Online MBA program was ranked among the nation's top 50 and 2nd in Florida by U.S. News and World Report.

2. The College of Education was reaccredited under the rigorous standards of the National Council for Accreditation of Teacher Education (NCATE).

\section{RESEARCH AWARDS/ACHIEVEMENTS}

1. USFSP attracted almost $\$ 3.4$ million in external research funding.

2. Dr. Heather Judkins was named to a research consortium funded by an $\$ 8.5$ million grant from the Gulf of Mexico Research Initiative.

3. Dr. James McHale received notice that he will be awarded an NIH grant for approximately $\$ 3$ million over the next five years for the project titled "Randomized Controlled Trial of Prenatal Coparenting Intervention for African American Fragile Families.”

\section{INSTITUTIONAL AWARDS/ACHIEVEMENTS}

1. The Kate Tiedemann College of Business was officially named following the announcement of a $\$ 10$ million gift. Ground was broken for a new, 68,000 square-foot building for the College.

2. USFSP made the inaugural list of 2015 STEM Jobs Approved Colleges published by STEM Jobs digital magazine. The list rates universities and colleges on their responsiveness and relevance to high-demand, high-growth STEM occupations. 


\section{Narrative}

Limit narrative to one page per section (a 9pg max). Arial 11 point font.

\section{Teaching and Learning}

\section{STRENGTHEN QUALITY AND REPUTATION OF ACADEMIC PROGRAMS AND UNIVERSITIES}

USFSP's Online MBA program was recognized nationally among the top 50 Online MBA programs by U.S. News and World Report. Moreover, the Online MBA program was ranked 2nd in Florida, 1st for Military Veterans in Florida, and 1st in Florida for faculty credentials and training.

Students enrolled in the Entrepreneurship program won the Association for Small Business and Entrepreneurship Pitch Competition. Students also were engaged in an entrepreneurial problem-solving project for Valpak, one of the University's community partners that ended with professional-level presentations to the corporation's executives.

USFSP's Mu Gamma Chapter of Beta Alpha Psi, the honor society for accounting and finance students, earned superior status by the Beta Alpha Psi International for the seventh year in a row.

USFSP faculty published nine books, including "Autism Spectrum Disorder: A Clinical Guide for General Practitioners" by Dr. V. Mark Durand and "Robert Pierpoint: A Life at CBS News," the first biography of the legendary journalist, by Dr. Tony Silvia.

Two USFSP College of Arts and Sciences faculty received history dissertation awards. Dr. Erica Heinsen-Roach was awarded the Parker-Schmitt Award of the European Section of the Southern Historical Association for 2014. Dr. Elisa Minoff was awarded the 2014 Cromwell Dissertation Prize by the American Society for Legal History.

Library faculty Tina Neville and Deborah Henry received the 2015 FLA Library Research Award from the Florida Library Association. Special Collections Librarian Jim Schnur was awarded the 2015 Presidential Citation by the Florida Historical Society.

Dr. Lyman Dukes was honored by the American College Personnel Association during its recognition of the 25th Anniversary of the Americans With Disabilities Act and reauthorization of the Higher Education Opportunity Act. Dukes was recognized for research that led to the development and adoption of Program Standards for those serving students with disabilities in post-secondary schools.

In May 2015, Dr. Joan Reid presented at the Legislative and Special Initiatives Committee of the Florida Statewide Council on Human Trafficking. Reid spoke about her research on girls with intellectual disabilities who are exploited in sex trafficking in Tampa and Miami.

Dr. Gary Mormino, professor emeritus of History, received the Florida Humanities Council's 2015 Florida Lifetime Achievement Award for Writing. 


\section{INCREASE DEGREE PRODUCTIVITY AND PROGRAM EFFICIENCY}

USFSP organized a large and diverse group of academic leaders to plan actions that target activities around improving the quality of entering students, retention, and graduation rates. During 2014-2015, USFSP awarded 842 undergraduate degrees in 34 majors and 222 degrees in graduate majors at our fall, spring and summer commencements. Of these receiving undergraduate degrees, 18 percent graduated with honors.

USFSP saw improvement in the number of graduates, 77 percent in June 2015, who are employed full time or who will head off to graduate school within a year of graduation. Their average starting salary was $\$ 34,500$.

USFSP has consistently increased in the number of Bachelor's degrees awarded without excess hours. In 2013-14, USFSP landed at 69 percent, up from 67 percent the year before.

Strategic Plan implementation efforts resulted in a proposal to launch a comprehensive first-year experience program titled Compass. Compass is designed to integrate new students into the academic and socio-cultural communities of USFSP. Activities target first-year student needs, success strategies, and peer coaching. Compass upper-division Peer Coaches help guide first-year students to be successfully involved on campus, in the classroom, and with faculty. The implementation of this cuttingedge program was targeted for Summer 2015, and preparation for the launch took place during the spring. Planning included consulting by a national expert, securing of funding, and hiring of professional staff and student employees.

First-generation students from low-income families, who received academic and support services through the federally funded TRIO program, performed extremely well. The retention rate was 82 percent and the progress rate was 92 percent.

A relationship with a critical longtime partner has recently been revived for mutual benefits. USFSP is now working with St. Petersburg College on several initiatives, including one with colleagues from USF in Tampa and USF Sarasota-Manatee. This new partnership aims to advance collective support of students who wish to transfer to the USF System after completion of their Associate's degree.

USFSP Student Affairs worked together with the Division of Administrative and Finance Services to renovate the recreation field through a creative collaboration with the Tampa Bay Rowdies soccer organization, which paid for a significant portion of the renovation in exchange for use of the field for team practices.

Student organizations, key opportunities for student involvement and retention, expanded again to 95, up from 77 during the previous year.

During the 2014-2015 year, Living Learning Communities (LLCs) were again a high priority at USFSP. LLCs bring together students with similar interests, assign them accommodations in close proximity to each other, and ensure that they take courses together and share a number of other academic experiences. USFSP launched the BioLife LLC with 12 students and expanded interest in the LLC model to two additional programs, the Environmental LLC and the Leadership LLC, which were planned in 2014-2015 for implementation in Fall 2015. 
INCREASE THE NUMBER OF DEGREES AWARDED IN S.T.E.M. AND OTHER PROGRAMS OF STRATEGIC EMPHASIS

USFSP was granted approval to offer a new Master's of Accountancy program. The MAcc is a 10-course (30 credit hour) graduate program that can be completed in hybrid format (some classes online, some on campus), or 100 percent on campus. The curriculum includes three core classes and seven electives.

USFSP also received support under an $\$ 8.5$ million TEAm Grant awarded by the Board of Governors to the Florida Consortium of Metropolitan Research Universities (Florida International University, the University of Central Florida, and the USF System) to increase the number of graduates in computer and information technology, and accountancy fields. USFSP devoted its funding to fulfilling the interventions required by the grant, including reducing class sizes, increasing tutoring resources, facilitating internships and awarding scholarships.

USFSP established an Institute for Data Analytics and Visualization, which will deliver courses and research on much sought-after topics of big data.

\section{Scholarship, Research and Innovation}

\section{STRENGTHEN QUALITY AND REPUTATION OF SCHOLARSHIP, RESEARCH AND INNOVATION}

USF St. Petersburg was well represented among the global community of Fulbright scholars, with seven individuals receiving the coveted award to support their work at institutions around the world.

V. Mark Durand received the 2015 American Psychological Association's Jacobson Award for Critical Thinking. The award is presented to an individual who has made "meritorious contributions to the field."

The College of Education was reaccredited under the rigorous standards of the National Council for Accreditation of Teacher Education (NCATE) through the Council for the Accreditation of Educator Preparation (CAEP).

In April 2015, more than 150 students participated in USFSP's Annual Student Research Symposiummore than ever in the 12-year history of the event.

Five King O'Neal scholars were among the 504 graduates recognized during the USFSP Spring Commencement ceremony in May 2015. The King O'Neal Scholars are recognized for having maintained a GPA of 4.0 .

Seven graduates of the USFSP College of Education's Educational Leadership master's program received promotions to top administrative positions at schools across Tampa Bay.

More than 3,300 records with approximately 4,100 unique items were added to the USFSP Digital Archive maintained by the Nelson Poynter Memorial Library. Continued emphasis was placed on the inclusion of faculty and student publications, as well as materials that document academic excellence in accordance with SACS accreditation. 


\section{Narrative}

\section{INCREASE RESEARCH AND COMMERCIALIZATION ACTIVITY}

Faculty from USFSP's Entrepreneurship and Journalism programs partnered with The Greenhouse of the City of St Petersburg, a unit dedicated to supporting and growing local businesses, to establish the capability for "backpack" journalism. Funding for the program was provided in the first of a series of legislative awards to support the Greenhouse initiative. Video equipment procured by this funding was used by USFSP Entrepreneurship students to record weekly sessions of "One Million Cups," a City initiative where business pitches are made. The City reports hosting 49 sessions with an estimated overall participation of 3,900 entrepreneurs, corporate representatives, and investors.

\section{INCREASE COLLABORATION AND EXTERNAL SUPPORT FOR RESEARCH ACTIVITY}

USFSP attracted almost \$3.4 million in external funding during the 2014-15 academic year.

Dr. Heather Judkins received funding of $\$ 103,000$ for year one as part of a collaboration with Nova Southeastern University for the project titled, "Deep-Pelagic Nekton Dynamics of the Gulf of Mexico." The total award to Dr. Judkins over three years will be $\$ 428,782$.

Dr. James McHale received notice that he will be awarded an NIH grant for approximately \$3 million over the next five years for the project titled, "Randomized Controlled Trial of Prenatal Co-parenting Intervention for African American Fragile Families."

The Project 10: Transition Education Network at USF St. Petersburg continued its collaboration with the State Personnel Development Grant Project (SPDG) at Florida Gulf Coast University to build capacity of Florida's school districts to increase school completion rates of students with disabilities.

\section{Community and Business Engagement}

\section{STRENGTHEN QUALITY AND REPUTATION OF COMMITMENT TO COMMUNITY AND BUSINESS} ENGAGEMENT

Plans for a yearlong celebration of USFSP's 50th Anniversary (2015-16) began with the formation of an Executive Planning Committee comprised of faculty and staff, as well as a number of community and business leaders. Early sponsorship commitments $(\$ 350,000+)$ included The Edwards Group (d.b.a. Tampa Bay Rowdies), Bright House Networks, Duke Energy, the City of St. Petersburg, the St. Petersburg Downtown Partnership, WUSF, and the Tampa Bay Times.

As part of the 50th Anniversary, the City of St. Petersburg approved the co-naming of Second Street South as University Way. Medians were constructed on Sixth Avenue South and 50 commemorative palm trees were planted by the City, creating a seamless transition from city to campus.

USFSP Regional Chancellor Sophia Wisniewska was named co-chair of St. Petersburg's new Innovation District, playing a key role in the city's effort to attract attention to our own innovation and research and that of our neighbors, including All Children's/Johns Hopkins Medicine, the St. Petersburg Downtown Partnership, the USF College of Marine Science and the Florida Institute of Technology. 


\section{Narrative}

\section{INCREASE LEVELS OF COMMUNITY AND BUSINESS ENGAGEMENT}

Partnerships with corporate and community leaders continued to be integral to thoughtful growth at USFSP. Among our successes in 2014-15 was a new, state-funded Center for Infant Mental Health with Johns Hopkins/All Children's Hospital.

USFSP partnered with Duke Energy to install a solar array on the top of the parking garage and, more importantly, will continue to work with Duke to explore the integration of storing solar energy in new battery systems.

USFSP was represented on the board of the Foundation for a Healthy St. Petersburg, a \$170 million initiative that provides grants to programs aimed at improving the health and well-being of underserved residents of Pinellas County.

Twenty-eight USFSP Accounting students, 22 undergraduates and six graduate students, once again completed an internship with the IRS Volunteer Income Tax Assistance (VITA) program. Following training in tax law and tax preparation software, each student then completed a minimum of 75 hours of field work at various sites throughout Pinellas County preparing tax returns for low- and moderateincome taxpayers.

As part of USFSP's Marketing program, students enrolled in the marketing capstone program continued to work with small local businesses and non-profit organizations to improve their marketing strategies. Beneficiaries included the Tampa Bay Theatre Festival, Aria Health + Wellness Institute, and Baby Cycle, a nonprofit providing diapers and other items for low-income families.

This year, USFSP forged new relationships with HCIQ and The Edwards Group, including the Tampa Bay Rowdies, and nurtured existing relationships with C1 Bank, the Dali Museum and ValPak.

\section{INCREASE COMMUNITY AND BUSINESS WORKFORCE}

In Spring 2015, USFSP received the final legislative funding (\$12 million) necessary to complete construction of a new building for the Kate Tiedemann College of Business. In Fall 2014, nearly 1,200 undergraduate and graduate students were enrolled in the College.

The Kate Tiedemann College of Business continues to offer the USFSP Banking Institute, which provides management training for the C1 Bank Management Associate Program in the bank's new headquarters in downtown St. Petersburg. This corporate partnership entered its fourth successful year of training the new executives.

A total of 14 Psychology students were graduated from USFSP's General Experimental Masters program in 2015. All of the incoming class ( $n=9$, beginning 2013) are employed ( $88 \%$ full time) in their chosen field. 


\section{Data Tables}

\section{FINANCIAL RESOURCES}

Table 1A. Education and General Revenues

Table 1B. Education and General Expenditures

Table 1C. Funding per Student FTE

Table 1D. Cost per Degree [New]

Table 1E. Other Budget Entities

Table 1F. Voluntary Support of Higher Education

PERSONNEL

Table 2A. Personnel Headcount

\section{ENROLLMENT}

Table 3A. Headcount Enrollment by Student Type

Table 3B. Full-time Equivalent (FTE) Enrollment

Table 3C. Enrollment by Method of Instruction

Table 3D. Headcount Enrollment by Military Status and Student Level

Table 3E. University Access Rate: Undergraduate Enrollment with Pell Grant

\section{UNDERGRADUATE EDUCATION}

Table 4A. Baccalaureate Degree Program Changes in AY 2014-2015

Table 4B. Retention Rates

Table 4C. First-Time-in-College (FTIC) Six-Year Graduation Rates (Full-time only)

Table 4D. FTIC Graduation Rates (Full- and Part-time)

Table 4E. AA Transfers Graduation Rates

Table 4F. Other Transfers Graduation Rates

Table 4G. Baccalaureate Degrees Awarded

Table 4H. Baccalaureate Degrees Awarded in Areas of Strategic Emphasis

Table 4I. Baccalaureate Degrees Awarded to Underrepresented Groups

Table 4J. Baccalaureate Degrees Without Excess Credit Hours

Table 4K. Undergraduate Course Offerings

Table 4L. Faculty Teaching Undergraduates

Table 4M. Student/Faculty Ratio

Table 4N. Licensure/Certification Exam: Nursing

Table 4O. Post-Graduation Metrics

\section{GRADUATE EDUCATION}

Table 5A. Graduate Degree Program Changes in AY 2014-2015

Table 5B. Graduate Degrees Awarded

Table 5C. Graduate Degrees Awarded in Areas of Strategic Emphasis

Table 5D. Licensure/Certification Exams: Graduate Programs

\section{RESEARCH \& ECONOMIC DEVELOPMENT}

Table 6A. Research and Development Expenditures

Table 6B. Centers of Excellence 


\section{Section 1 - Financial Resources}

TABLE 1A. University Education and General Revenues (Not Adjusted for Inflation)

\begin{tabular}{lrrrrr} 
& $\begin{array}{r}\mathbf{2 0 1 1 - 1 2} \\
\text { Actual }\end{array}$ & $\begin{array}{r}\mathbf{2 0 1 2 - 1 3} \\
\text { Actual }\end{array}$ & $\begin{array}{r}\mathbf{2 0 1 3 - 1 4} \\
\text { Actual }\end{array}$ & $\begin{array}{r}\mathbf{2 0 1 4 - 1 5} \\
\text { Actual }\end{array}$ & $\begin{array}{r}\mathbf{2 0 1 5 - 1 6} \\
\text { Estimates }\end{array}$ \\
\hline MAIN OPERATIONS & & & & & \\
\hline Recurring State Funds & $\$ 21,161,442$ & $\$ 21,974,862$ & $\$ 22,639,104$ & $\$ 22,934,103$ & $\$ 24,372,544$ \\
\hline Non-Recurring State Funds & $\$ 241,627$ & $-\$ 5,111,531$ & $\$ 131,000$ & $\$ 1,350,000$ & $\$ 3,023,354$ \\
\hline Tuition & $\$ 15,649,557$ & $\$ 17,204,867$ & $\$ 17,315,935$ & $\$ 16,047,919$ & $\$ 17,804,435$ \\
\hline Tuition Differential Fee & $\$ 1,965,224$ & $\$ 3,438,880$ & $\$ 3,231,124$ & $\$ 2,994,726$ & $\$ 3,500,000$ \\
\hline Misc. Fees \& Fines & $\$ 214,107$ & $\$ 180,959$ & $\$ 199,574$ & $\$ 247,659$ & $\$ 400,565$ \\
\hline Phosphate Research TF & $\$ 0$ & $\$ 0$ & $\$ 0$ & $\$ 0$ & $\$ 0$ \\
\hline Federal Stimulus Funds & $\$ 0$ & $\$ 0$ & $\$ 0$ & $\$ 0$ & $\$ 0$ \\
\hline SUBTOTAL & $\$ 39,231,957$ & $\$ 37,688,037$ & $\$ 43,516,737$ & $\$ 43,574,407$ & $\$ 49,100,898$ \\
\multicolumn{1}{c}{ TOTAL } & $\$ 39,231,957$ & $\$ 37,688,037$ & $\$ 43,516,737$ & $\$ 43,574,407$ & $\$ 49,100,898$
\end{tabular}

Recurring State Funds: include general revenue and lottery education \& general (E\&G) appropriations and any administered funds provided by the state, including annual adjustments of risk management insurance premiums for the estimated year. This does not include technical adjustments or transfers made by universities after the appropriation. Please note: 2013-14 revenues include the non-recurring $\$ 300 \mathrm{M}$ system budget reduction. Sources: SUS Final Amendment Packages were used for actual years; and, the Allocation Summary and Workpapers were used for the estimated year. Non-Recurring State Funds: include general revenue and lottery education \& general appropriations and any administered funds provided by the state. This does not include technical adjustments or transfers made by Universities after the appropriation. Source: non-recurring appropriations section of the annual Allocation Summary and Workpapers that include all other non-recurring budget amendments allocated later in the fiscal year. Note on Performance Funding: the State investment piece of performance funding is reported in the 'Non-Recurring State Funds' and the Institutional investment piece is reported within 'Recurring State Funds'. Tuition: Actual resident \& non-resident tuition revenues collected from students, net of fee waivers. Source: Operating Budget, Report 625 Schedule I-A. Tuition Differential Fee: Actual tuition differential revenues collected from undergraduate students. Source: Operating Budget, Report 625 Schedule I-A. Miscellaneous Fees \& Fines: Other revenue collections include items such as application fees, late registration fees, library fines, miscellaneous revenues. This is the total revenue from Report 625 minus tuition and tuition differential fee revenues. This does not include local fees. Source: Operating Budget, Report 625 - Schedule I-A. Phosphate Research Trust Fund: State appropriation for the Florida Industrial and Phosphate Research Institute at the University of South Florida (for history years through 2012-13); beginning 2013-14 the Phosphate Research Trust Fund is appropriated through Florida Polytechnic University. Other Operating Trust Funds. For UF-IFAS and UF-HSC, actual revenues from the Incidental Trust Funds and Operations \& Maintenance Trust Fund are provided by the University of Florida. Source: Final Amendment Package. Federal Stimulus Funds: Non-recurring American Recovery and Reinvestment Act funds appropriated by the state. Source: SUS Final Amendment Package. This data is not adjusted for inflation. 


\section{Section 1 - Financial Resources (continued)}

\section{TABLE 1B. University Education and General Expenditures (Not Adjusted for Inflation)}

\begin{tabular}{lrrrrr} 
& $\mathbf{2 0 1 0 - 1 1 *}^{*}$ & $\mathbf{2 0 1 1 - 1 2}^{*}$ & $\mathbf{2 0 1 2 - 1 3}$ & $\mathbf{2 0 1 3 - 1 4}$ & $\mathbf{2 0 1 4 - 1 5}$ \\
\hline MAIN OPERATIONS & & & & & \\
\hline Instruction/Research & $\$ 21,123,344$ & $\$ 21,200,464$ & $\$ 24,698,212$ & $\$ 26,960,714$ & $\$ 29,517,329$ \\
\hline Administration and Support & $\$ 3,366,169$ & $\$ 2,653,731$ & $\$ 4,811,738$ & $\$ 3,807,349$ & $\$ 4,927,612$ \\
\hline PO\&M & $\$ 3,574,046$ & $\$ 3,690,915$ & $\$ 4,036,733$ & $\$ 4,431,979$ & $\$ 4,619,031$ \\
\hline Student Services & $\$ 1,424,880$ & $\$ 1,510,047$ & $\$ 1,958,948$ & $\$ 2,108,819$ & $\$ 2,384,764$ \\
\hline Library/Audio Visual & $\$ 1,427,612$ & $\$ 1,449,515$ & $\$ 1,422,051$ & $\$ 1,320,155$ & $\$ 1,543,891$ \\
\hline Other & $\$ 0$ & $\$ 0$ & $\$ 0$ & $\$ 0$ & $\$ 0$ \\
\hline TOTAL & $\$ 30,916,051$ & $\$ 30,504,672$ & $\$ 36,927,682$ & $\$ \mathbf{3 8 , 6 2 9 , 0 1 6}$ & $\$ \mathbf{4 2 , 9 9 2 , 6 2 7}$ \\
TOTAL & $\$ 30,916,051$ & $\$ \mathbf{3 0 , 5 0 4 , 6 7 2}$ & $\$ 36,927,682$ & $\$ \mathbf{3 8 , 6 2 9 , 0 1 6}$ & $\$ \mathbf{4 2 , 9 9 2 , 6 2 7}$
\end{tabular}

The table reports the actual and estimated amount of expenditures from revenues appropriated by the legislature for each fiscal year. The expenditures are classified by Program Component (e.g., Instruction/Research, PO\&M, Administration, etc...) for activities directly related to instruction, research and public service. The table does not include expenditures classified as non-operating expenditures (e.g., to service asset-related debts), and therefore excludes a small portion of the amount appropriated each year by the legislature. Note*: FY 2012-2013 reflects a change in reporting expenditures from prior years due to the new carry-forward reporting requirement as reflected in the 2013-2014 SUS Operating Budget Reports. Since these expenditures will now include carry-forward expenditures, these data are no longer comparable to the current-year revenues reported in table $1 \mathrm{~A}$, or prior year expenditures in table 1B. This data is not adjusted for inflation.

Instruction \& Research: Includes expenditures for state services related to the instructional delivery system for advanced and professional education. Includes functions such as; all activities related to credit instruction that may be applied toward a postsecondary degree or certificate; non-project research and service performed to maintain professional effectives; individual or project research; academic computing support; academic source or curriculum development. Source: Operating Budget Summary - Expenditures by Program Activity (or Report 645). Administration \& Support Services: Expenditures related to the executive direction and leadership for university operations and those internal management services which assist and support the delivery of academic programs. Source: Operating Budget Summary - Expenditures by Program Activity (or Report 645). P0\&M: Plant Operations \& Maintenance expenditures related to the cleaning and maintenance of existing grounds, the providing of utility services, and the planning and design of future plant expansion and modification. Student Services: Includes resources related to physical, psychological, and social well-being of the student. Includes student service administration, social and cultural development, counseling and career guidance, financial aid, and student admissions and records. Other: includes Institutes and Research Centers, Radio/TV, Museums and Galleries, Intercollegiate Athletics, Academic Infrastructure Support Organizations. Source: Operating Budget Summary - Expenditures by Program Activity (or Report 645). 


\section{Section 1 - Financial Resources (continued)}

\section{TABLE 1C. Funding per Full-Time Equivalent (FTE) Student (Not Adjusted for Inflation)}

\begin{tabular}{lccccc} 
& $\mathbf{2 0 1 0 - 1 1}$ & $\mathbf{2 0 1 1 - 1 2}$ & $\mathbf{2 0 1 2 - 1 3}$ & $\mathbf{2 0 1 3 - 1 4}$ & $\mathbf{2 0 1 4 - 1 5}$ \\
\hline State Appropriation (GR \& Lottery) & $\$ 5,885$ & $\$ 5,199$ & $\$ 3,859$ & $\$ 5,467$ & $\$ 6,085$ \\
Tuition \& Fees (State-funded Aid) & $\$ 980$ & $\$ 807$ & $\$ 760$ & $\$ 725$ & $\$ 627$ \\
Tuition \& Fees (from Student) & $\$ 2,920$ & $\$ 3,523$ & $\$ 4,005$ & $\$ 4,256$ & $\$ 4,206$ \\
Other Trust Funds & $\$ 482$ & $\$ 0$ & $\$ 0$ & $\$ 0$ & $\$ 0$ \\
\hline TOTAL & $\$ 10,266$ & $\$ 9,529$ & $\$ 8,624$ & $\$ 10,448$ & $\$ 10,918$
\end{tabular}

Notes: State Appropriations includes General Revenues and Lottery funds that are directly appropriated to the university as reported in Final Amendment Package. This does not include appropriations for special units (e.g., IFAS, Health Science Centers, and Medical Schools). Tuition and Fee revenues include tuition and tuition differential fee and E\&G fees (e.g., application, late registration, and library fees/fines) as reported on the from the Operating Budget 625 reports. Other local fees that do not support E\&G activities are not included here (see Board of Governors Regulation 7.003). To more accurately report the full contribution from the State, this table reports the state-funded financial aid separately from the tuition and fee payments universities receive from students (which may include federal financial aid dollars). The state-funded gift aid includes grants and scholarships as reported by universities to Board during the academic year in the State University Database (SUDS). Other Trust funds (e.g., Federal Stimulus for 2009-10 and 2010-11 only) as reported in Final Amendment Package. Full-time Equivalent enrollment is based on actual FTE, not funded FTE; and, does not include Health-Science Center funds or FTE. This data is based on the standard IPEDS definition of FTE, equal to 30 credit hours for undergraduates and 24 for graduates. This data is not adjusted for inflation.

\section{TABLE 1D. Cost per Degree (Full Expenditures per Bachelor's Degree - Not Adjusted for Inflation)}

2007-11 2008-12 2009-13 2010-14 2011-15

TOTAL

Reported at the USF System Level

Notes: Full expenditures include direct instructional, research and public service expenditures and the undergraduate portion of indirect expenditures (e.g., academic administration, academic advising, student services, libraries, university support, and Plant Operations and Maintenance). For each year, the full expenditures were divided by undergraduate fundable student credit hours to calculate the full expenditures per credit hour, and then multiplied by 30 credit hours to represent the annual undergraduate expenditures. The annual undergraduate expenditures for each of the four years was summed to provide an average undergraduate expenditures per (120 credit) degree. Source: State University Database System (SUDS), Expenditure Analysis: Report IV. This data is not adjusted for inflation. 


\section{Section 1 - Financial Resources (continued)}

TABLE 1E. University Other Budget Entities (Not Adjusted for Inflation) 2010-11 2011-12 2012-13 2013-14 2014-15

\section{Auxiliary Enterprises}

Revenues n/a $\$ 8,207,956$ $\$ 12,298,149$ $\$ 11,699,937$

$\$ 12,305,332$

Expenditures

\section{Contracts \& Grants}

\begin{tabular}{lccccc}
$\begin{array}{l}\text { Revenues } \\
\text { Expenditures } \\
\text { Local Funds }\end{array}$ & $\mathrm{n} / \mathrm{a}$ & $\$ 3,228,779$ & $\$ 3,730,136$ & $\$ 3,356,232$ & $\$ 2,865,598$ \\
\hline $\begin{array}{l}\text { Revenues } \\
\text { Expenditures }\end{array}$ & $\mathrm{n} / \mathrm{a}$ & $\$ 3,614,154$ & $\$ 4,065,874$ & $\$ 3,869,834$ & $\$ 3,920,330$ \\
\hline & $\mathrm{n} / \mathrm{a}$ & $\$ 3,875,688$ & $\$ 4,117,824$ & $\$ 4,067,496$ & $\$ 3,814,274$ \\
& $\mathrm{n} / \mathrm{a}$ & $\$ 1,832,342$ & $\$ 2,743,811$ & $\$ 3,675,343$ & $\$ 2,871,627$
\end{tabular}

Notes: Revenues do not include transfers. Expenditures do not include non-operating expenditures. Auxiliary Enterprises are self-supported through fees, payments and charges. Examples include housing, food services, bookstores, parking services, health centers. Contract \& Grants resources are received from federal, state or private sources for the purposes of conducting research and public service activities. Local Funds are associated with student activity (supported by the student activity fee), student financial aid, concessions, intercollegiate athletics, technology fee, green fee, and student life \& services fee. Faculty Practice Plan revenues/receipts are funds generated from faculty practice plan activities. Faculty Practice Plan expenditures include all expenditures relating to the faculty practice plans, including transfers between other funds and/or entities. This may result in double counting in information presented within the annual report. Source: Operating Budget, Report 615. This data is not adjusted for inflation. 


\section{Section 2 - Personnel}

\section{TABLE 2A. Personnel Headcount (in Fall term only)}

\begin{tabular}{lccccc} 
& $\mathbf{2 0 1 0}$ & $\mathbf{2 0 1 1}$ & $\mathbf{2 0 1 2}$ & $\mathbf{2 0 1 3}$ & $\mathbf{2 0 1 4}$ \\
\hline Full-time Employees & & & & & \\
\hline Tenured Faculty & 56 & 58 & 58 & 58 & 64 \\
Tenure-track Faculty & 24 & 25 & 25 & 28 & 26 \\
Non-Tenure Track Faculty & 27 & 24 & 30 & 41 & 38 \\
Instructors Without Faculty Status & 0 & 0 & 0 & 0 & 0 \\
Graduate Assistants/Associates & 0 & 0 & 0 & 0 & 0 \\
Non-Instructional Employees & 194 & 208 & 224 & 257 & 264 \\
\hline FULL-TIME SUBTOTAL & $\mathbf{3 0 1}$ & $\mathbf{3 1 5}$ & $\mathbf{3 3 7}$ & $\mathbf{3 8 4}$ & $\mathbf{3 9 2}$ \\
& & & & & \\
Part-time Employees & 0 & 1 & 1 & 1 & 1 \\
\hline Tenured Faculty & 0 & 2 & 0 & 0 & 2 \\
Tenure-track Faculty & 120 & 116 & 138 & 135 & $139^{*}$ \\
Non-Tenure Track Faculty & 0 & 0 & 0 & 0 & $0^{*}$ \\
Instructors Without Faculty Status & 33 & 28 & 31 & 37 & 46 \\
Graduate Assistants/Associates & 224 & 2 & 0 & 1 & 1 \\
Non-Instructional Employees & $\mathbf{3 7 7}$ & $\mathbf{1 4 9}$ & $\mathbf{1 7 0}$ & $\mathbf{1 7 4}$ & $\mathbf{1 8 9}$ \\
\hline PART-TIME SUBTOTAL & & & & & \\
\hline \multicolumn{1}{c}{ TOTAL } & $\mathbf{6 7 8}$ & $\mathbf{4 6 4}$ & $\mathbf{5 0 7}$ & $\mathbf{5 5 8}$ & $\mathbf{5 8 1}$
\end{tabular}

Note: This table is based on the annual IPEDS Human Resources Survey, and provides full- and part-time medical and non-medical staff by faculty status and primary function/occupational activity. Tenured and Tenure-Track Faculty include those categorized within instruction, research, or public service. Non-Tenure Track Faculty includes adjunct faculty (on annual and less than annual contracts) and faculty on multi-year contracts categorized within instruction, research, or public service. Instructors Without Faculty Status includes postdoctoral research associates, and individuals hired as a staff member primarily to do research on a 3-year contract without tenure eligibility categorized within instruction, research, or public service. Non-Instructional Employees includes all executive, administrative and managerial positions regardless of faculty status; as well as, other support and service positions regardless of faculty status. Note: The universities vary on how they classify adjuncts (some include them as non-tenure track faculty while others do not consider them faculty and report them as instructors without faculty status) and part-time non-instructional employees. 


\section{Section 3 - Enrollment}

\section{TABLE 3A. Headcount Enrollment by Student Type and Level}

\begin{tabular}{cccccc} 
& Fall 2010 & Fall 2011 & Fall 2012 & Fall 2013 & Fall 2014* \\
\hline TOTAL & 4,057 & 4,407 & 4,690 & 4,740 & 4,596
\end{tabular}

UNDERGRADUATE

\begin{tabular}{lccccc}
\hline FTIC (Regular Admit) & 1,284 & 1,466 & 1,669 & 1,624 & 1,501 \\
FTIC (Profile Admit) & 9 & 15 & 16 & 12 & 17 \\
AA Transfers & 1,333 & 1,447 & 1,460 & 1,446 & 1,427 \\
Other Transfers & 808 & 865 & 869 & 867 & 736 \\
\hline Subtotal & $\mathbf{3 , 4 3 4}$ & $\mathbf{3 , 7 9 3}$ & $\mathbf{4 , 0 1 4}$ & $\mathbf{3 , 9 4 9}$ & $\mathbf{3 , 6 8 1}$
\end{tabular}

GRADUATE

\begin{tabular}{lccccc}
\hline Master's & 403 & 393 & 457 & 552 & 530 \\
Research Doctoral & 0 & 0 & 0 & 0 & 0 \\
Professional Doctoral & 0 & 0 & 0 & 0 & 0 \\
Dentistry & 0 & 0 & 0 & 0 & 0 \\
Law & 0 & 0 & 0 & 0 & 0 \\
Medicine & 0 & 0 & 0 & 0 & 0 \\
Nursing Practice & 0 & 0 & 0 & 0 & 0 \\
Pharmacy & 0 & 0 & 0 & 0 & 0 \\
Physical Therapist & 0 & 0 & 0 & 0 & 0 \\
Veterinary Medicine & 0 & 0 & 0 & 0 & 0 \\
Other & 0 & 0 & 0 & 0 & 0 \\
\hline Subtotal & $\mathbf{4 0 3}$ & $\mathbf{3 9 3}$ & $\mathbf{4 5 7}$ & $\mathbf{5 5 2}$ & $\mathbf{5 3 0}$
\end{tabular}

\section{UNCLASSIFIED}

\begin{tabular}{lccccc}
\hline HS Dual Enrolled & 0 & 0 & 0 & 0 & 0 \\
Other & 220 & 221 & 219 & 239 & $385^{\star}$ \\
\hline Subtotal & 220 & $\mathbf{2 2 1}$ & $\mathbf{2 1 9}$ & $\mathbf{2 3 9}$ & $\mathbf{3 8 5}$
\end{tabular}

Note: This table reports the number of students enrolled at the university by student type categories. The determination for undergraduate, graduate and unclassified is based on the institutional class level values. Unclassified refers to a student who has not yet been formally admitted into a degree program but is enrolled. The student type for undergraduates is based on the Type of Student at Time of Most Recent Admission. The student type for graduates is based on the degree that is sought and the student CIP code.

Note*: In Fall 2014, students classified by the university as post-baccalaureate are counted as "other" unclassified for the purposes of this table. This differs from the methodology used to produce data for the online interactive enrollment tool (on the Board's website) which includes post-bacs as undergraduates regardless of degree sought. Board staff will review this definition with university staff during the Summer Data Workshop and may revise it for next year's report. 
Section 3 - Enrollment (continued)

TABLE 3B. Full-Time Equivalent (FTE) Enrolliment [State Fundable only]

2012-13

State-

Funded 2013-14

StateFunded
2014-15

StateFunded

Actual

\section{FLORIDA RESIDENTS}

\begin{tabular}{lcc|cccc}
\hline Lower-Division & 657 & 1,156 & 657 & 1,015 & 657 & 893 \\
Upper-Division & 1,486 & 1,760 & 1,486 & 1,711 & 1,486 & 1690 \\
Master's (GRAD I) & 227 & 273 & 227 & 295 & 227 & 314 \\
Doctoral (GRAD II) & 0 & 0 & 0 & 0 &. & 1 \\
\hline Subtotal & $\mathbf{2 , 3 7 0}$ & $\mathbf{3 , 1 8 9}$ & $\mathbf{2 , 3 7 0}$ & $\mathbf{3 , 0 2 1}$ & $\mathbf{2 , 3 7 0}$ & $\mathbf{1 9 1 3}$
\end{tabular}

\section{NON-FLORIDA RESIDENTS}

\begin{tabular}{lcc|cccc}
\hline Lower-Division & $\cdot$ & 36 &. & 41 &. & 37 \\
Upper-Division &. & 39 &. & 42 &. & 50 \\
Master's (GRAD I) &. & 12 &. & 19 &. & 10 \\
Doctoral (GRAD II) &. & 0 &. & 0 &. & 0 \\
\hline Subtotal & $\mathbf{0}$ & $\mathbf{8 7}$ & $\mathbf{0}$ & $\mathbf{1 0 2}$ &. & $\mathbf{7 5}$
\end{tabular}

\section{TOTAL FTE}

\begin{tabular}{lcc|cccc}
\hline Lower-Division & $\cdot$ & 1,192 & $\cdot$ & 1,056 & - & 930 \\
Upper-Division & $\cdot$ & 1,800 & $\cdot$ & 1,753 & - & 1739 \\
Master's (GRAD I) & $\cdot$ & 285 & $\cdot$ & 314 & - & 323 \\
Doctoral (GRAD II) &. & 0 & $\cdot$ & 0 & - & 1 \\
\hline Total & $\mathbf{2 , 3 7 0}$ & $\mathbf{3 , 2 7 8}$ & $\mathbf{2 , 3 7 0}$ & $\mathbf{3 , 1 2 3}$ & $\mathbf{2 , 3 7 0}$ & $\mathbf{2 , 9 9 3}$ \\
\hline Total (US Definition) & $\mathbf{3 , 1 6 0}$ & $\mathbf{4 , 3 6 8}$ & $\mathbf{3 , 1 6 0}$ & $\mathbf{4 , 1 6 4}$ & $\mathbf{3 , 1 6 0}$ & $\mathbf{3 , 9 9 1}$ \\
\hline
\end{tabular}

Notes: Full-time Equivalent (FTE) student is a measure of instructional effort (and student activity) that is based on the number of credit hours that students enroll by course level. FTE is based on the Florida definition, which divides undergraduate credit hours by 40 and graduate credit hours by 32 (US definition based on Undergraduate FTE = 30 and Graduate FTE = 24 credit hours). In 2013-14, the Florida Legislature chose to no longer separate funded non-resident FTE from funded resident FTE. Funded enrollment as reported in the General Appropriations Act and Board of Governors' Allocation Summary. Actual enrollment only reports 'state-fundable' FTE as reported by Universities to the Board of Governors in the Student Instruction File (SIF). Totals are actual and may not equal sum of reported student levels due to rounding of student level FTE. Total FTE are equal in tables $3 \mathrm{~B}$ and $3 \mathrm{C}$. 
Section 3 - Enrollment (continued)

TABLE 3C. Full-Time Equivalent (FTE) Enrollment by Method of Instruction 2010-11 2011-12 2012-13 2013-14 2014-15

TRADITIONAL

\begin{tabular}{lrrrrr}
\hline Lower-Division & 748 & 859 & 941 & 884 & 756 \\
Upper-Division & 1,139 & 1,082 & 1,041 & 979 & 996 \\
Master's (GRAD 1) & 197 & 177 & 173 & 178 & 161 \\
Doctoral (GRAD 2) & 0 & 0 & 0 & 0 & 0 \\
TOTAL & $\mathbf{2 , 0 8 5}$ & $\mathbf{2 , 1 1 8}$ & $\mathbf{2 , 1 5 5}$ & $\mathbf{2 , 0 4 1}$ & $\mathbf{1 9 1 3}$
\end{tabular}

HYBRID

$\begin{array}{llrrrr}\text { Lower-Division } & 0 & 3 & 7 & 2 & 14 \\ \text { Upper-Division } & 0 & 19 & 20 & 48 & 47 \\ \text { Master's (GRAD 1) } & 1 & 2 & 0 & 3 & 14 \\ \text { Doctoral (GRAD 2) } & 0 & 0 & 0 & 0 & 0 \\ \text { TOTAL } & 1 & \mathbf{2 4} & \mathbf{2 7} & \mathbf{5 3} & \mathbf{7 5}\end{array}$

DISTANCE LEARNING

\begin{tabular}{lrrrrr} 
Lower-Division & 199 & 226 & 244 & 170 & 160 \\
Upper-Division & 522 & 632 & 739 & 726 & 696 \\
Master's (GRAD 1) & 62 & 87 & 112 & 133 & 148 \\
$\begin{array}{l}\text { Doctoral (GRAD 2) } \\
\text { TOTAL }\end{array}$ & & & & & 1 \\
TOTAL & 783 & 945 & 1,095 & $\mathbf{1 , 0 2 9}$ & $\mathbf{1 0 0 5}$ \\
\hline Lower-Division & & & & & \\
Upper-Division & 947 & 1,088 & 1,192 & 1,056 & 930 \\
Master's (GRAD 1) & 1,661 & 1,733 & 1,800 & 1,753 & 1739 \\
Doctoral (GRAD 2) & 260 & 266 & 285 & 314 & 323 \\
TOTAL & 0 & 0 & 0 & 0 & 1 \\
& $\mathbf{2 , 8 6 8}$ & $\mathbf{3 , 0 8 7}$ & $\mathbf{3 , 2 7 7}$ & $\mathbf{3 , 1 2 3}$ & $\mathbf{2 9 9 3}$
\end{tabular}

Note: Full-time Equivalent (FTE) student is a measure of instructional effort (and student activity) that is based on the number of credit hours that students enroll by course level. FTE is based on the Florida definition, which divides undergraduate credit hours by 40 and graduate credit hours by 32. Distance Learning is a course in which at least 80 percent of the direct instruction of the course is delivered using some form of technology when the student and instructor are separated by time or space, or both (per 1009.24(17), F.S.). Hybrid is a course where $50 \%$ to $79 \%$ of the instruction is delivered using some form of technology, when the student and instructor are separated by time or space, or both (per SUDS data element 2052). Traditional (and Technology Enhanced) refers to primarily face to face instruction utilizing some form of technology for delivery of supplemental course materials for no more than $49 \%$ of instruction (per SUDS data element 2052). Totals are actual and may not equal sum of reported student levels due to rounding of student level FTE. Total FTE are equal in tables 3B and 3C. 


\section{Section 3 - Enrollment (continued)}

TABLE 3D. Headcount Enrollment by Military Status and Student Level

Fall $2010 \quad$ Fall $2011 \quad$ Fall $2012 \quad$ Fall $2013 \quad$ Fall 2014

\begin{tabular}{|c|c|c|c|c|c|}
\hline \multicolumn{6}{|l|}{ MILITARY } \\
\hline Unclassified & 2 & & 1 & 3 & 3 \\
\hline Undergraduate & 99 & 117 & 136 & 126 & 119 \\
\hline Master's (GRAD 1) & 8 & 10 & 16 & 15 & 22 \\
\hline Doctoral (GRAD 2) & 0 & 0 & 0 & 0 & 0 \\
\hline Subtotal & 109 & 127 & 153 & 144 & 144 \\
\hline \multicolumn{6}{|l|}{ DEPENDENTS } \\
\hline Unclassified & & & & 1 & 0 \\
\hline Undergraduate & 14 & 17 & 23 & 24 & 19 \\
\hline Master's (GRAD 1) & 2 & 1 & 1 & 3 & 4 \\
\hline Doctoral (GRAD 2) & 0 & 0 & 0 & 0 & 0 \\
\hline Subtotal & 16 & 18 & 24 & 28 & 23 \\
\hline \multicolumn{6}{|l|}{ NON-MILITARY } \\
\hline Unclassified & 218 & 221 & 218 & 234 & 228 \\
\hline Undergraduate & 3,321 & 3,659 & 3,855 & 3,800 & 3,697 \\
\hline Master's (GRAD 1) & 393 & 382 & 440 & 534 & 504 \\
\hline Doctoral (GRAD 2) & 0 & 0 & 0 & 0 & 0 \\
\hline Subtotal & 3,932 & 4,262 & 4,513 & 4,568 & 4,429 \\
\hline TOTAL & 4,057 & 4,407 & 4,690 & 4,740 & 4,596 \\
\hline
\end{tabular}

Note: This table provides trend data on the number of students enrolled based on their military status. Military includes students who were classified as Active Duty, Veterans, National Guard, or Reservist.. Eligible Dependents includes students who were classified as eligible dependents (dependents who received veteran's benefits). Non-Military includes all other students.

\section{TABLE 3E. University Access Rate: Undergraduate Enrollment with Pell Grant}

\begin{tabular}{lccccc} 
& Fall 2010 & Fall 2011 & Fall 2012 & Fall 2013 & Fall 2014 \\
\hline Pell Grant Recipients & 1,156 & 1,418 & 1,567 & 1,577 & 1,589 \\
\hline Percent with Pell Grant & $33.84 \%$ & $37.57 \%$ & $39.20 \%$ & $40.03 \%$ & $41.60 \%$
\end{tabular}

Note: This table reports the University's Access Rate, which is a measure of the percentage of undergraduate students who have received a federal Pell grant award during a given Fall term. The top row reports the number of students who received a Pell Grant award. The bottom row provides the percentage of eligible students that received a Pell Grant award. This metric was included in the Board of Governors Performance Based Funding Model in 2014 - for more information see: http://www.flbog.edu/about/budget/performance_funding.php. 


\section{Section 4 - Undergraduate Education}

\section{TABLE 4A. Baccalaureate Degree Program Changes in AY 2014-15}

\begin{tabular}{|l|l|l|l|l|l|}
\hline \multicolumn{1}{|c|}{ Title of Program } & $\begin{array}{c}\text { Six-digit } \\
\text { CIP } \\
\text { Code }\end{array}$ & \multicolumn{1}{|c|}{$\begin{array}{c}\text { Degree } \\
\text { Level }\end{array}$} & $\begin{array}{c}\text { Date of } \\
\text { UBOT } \\
\text { Action }\end{array}$ & $\begin{array}{c}\text { Starting } \\
\text { or Ending } \\
\text { Term }\end{array}$ & Comments \\
\hline New Programs & & & & & \\
\hline None & & & & & \\
\hline & & & & \\
\hline Terminated Programs & & & & \\
\hline None & & & & \\
\hline & & & \\
\hline Programs Suspended for New Enrollments & & & \\
\hline None & & & \\
\hline \\
\hline New Programs Considered By University But Not Approved
\end{tabular}

Note: This table does not include new majors or concentrations added under an existing degree program CIP Code. This table reports the new and terminated program changes based on Board action dates between May 5, 2014 and May 4, 2015.

New Programs are proposed new degree programs that have been completely through the approval process at the university and, if appropriate, the Board of Governors. Does not include new majors or concentrations added under an existing degree program CIP Code.

Terminated Programs are degree programs for which the entire CIP Code has been terminated and removed from the university's inventory of degree programs. Does not include majors or concentrations terminated under an existing degree program CIP Code if the code is to remain active on the academic degree inventory.

Programs Suspended for New Enrollments are degree programs for which enrollments have been temporarily suspended for the entire CIP Code, but the program CIP Code has not been terminated. Does not include majors or concentrations suspended under an existing degree program CIP Code if the code is to remain active on the academic degree inventory and new enrollments in any active major will be reported. Programs included in this list may have been suspended for new enrollments sometime in the past and have continued to be suspended at least one term of this academic year.

New Programs Considered by University But Not Approved includes any programs considered by the university board of trustees, or any committee of the board, but not approved for implementation. Also include any programs that were returned prior to board consideration by the university administration for additional development, significant revisions, or re-conceptualization; regardless of whether the proposal was eventually taken to the university board for approval. Count the returns once per program, not multiple times the proposal was returned for revisions, unless there is a total re-conceptualization that brings forward a substantially different program in a different CIP Code. 


\section{Section 4 - Undergraduate Education (continued)}

\section{TABLE 4B. Full-time, First-Time-in-College (FTIC) Retention Rates \\ Retained in the Second Fall Term at Same University}

$\begin{array}{lccccc} & \mathbf{2 0 1 0 - 1 1} & \mathbf{2 0 1 1 - 1 2} & \mathbf{2 0 1 2 - 1 3} & \mathbf{2 0 1 3 - 1 4} & \mathbf{2 0 1 4 - 1 5} \\ \text { Cohort Size } & 470 & 576 & 681 & 547 & 444\end{array}$

Retained at USF-St. Pete

\begin{tabular}{cccccc}
\hline with Any GPA & $69 \%$ & $64 \%$ & $60 \%$ & $65 \%$ & $70 \%$ \\
\hline with GPA 2.0 or higher & $61.49 \%$ & $58.85 \%$ & $57.27 \%$ & $61.61 \%$ & $66.89 \%$ \\
\hline Retained within USF-System & & & & & \\
\hline with Any GPA & $78 \%$ & $80 \%$ & $76 \%$ & $78 \%$ & $79 \%$ \\
\hline with GPA 2.0 or higher & $70.43 \%$ & $75.00 \%$ & $73.13 \%$ & $74.22 \%$ & $76.35 \%$
\end{tabular}

Notes: Cohorts are based on undergraduate students who enter the institution in the Fall term (or Summer term and continue into the Fall term). Percent Retained with Any GPA is based on student enrollment in the Fall term following their first year. Percent Retained with GPA Above 2.0 is based on student enrollment in the Fall term following their first years for those students with a GPA of 2.0 or higher at the end of their first year (Fall, Spring, Summer). The most recent year of Retention data is based on preliminary data (SIFP file) that is comparable to the final data (SIF file) but may be revised in the following years based on changes in student cohorts.

\section{TABLE 4C. Full-time, First-Time-in-College (FTIC) Six-Year Graduation Rates}

\begin{tabular}{cccccc} 
Term of Entry & $\mathbf{2 0 0 5 - 1 1}$ & $\mathbf{2 0 0 6 - 1 2}$ & $\mathbf{2 0 0 7 - 1 3}$ & $\mathbf{2 0 0 8 - 1 4}$ & $\mathbf{2 0 0 9 - 1 5}$ \\
\hline Cohort Size & 174 & 271 & 225 & 374 & 488 \\
\hline$\%$ Graduated & $30 \%$ & $33 \%$ & $43 \%$ & $32 \%$ & $38 \%$ \\
\hline \% Still Enrolled & $7 \%$ & $7 \%$ & $4 \%$ & $5 \%$ & $5 \%$ \\
\hline$\%$ Success Rate & $37 \%$ & $40 \%$ & $47 \%$ & $36 \%$ & $43 \%$
\end{tabular}

Notes: Cohorts are based on FTIC undergraduate students who enter the institution in the Fall term (or Summer term and continue into the Fall term). Percent Graduated reports the percent of FTICs who graduated from the same institution within six years. This metric does not include students who enrolled as part-time students (in their first year), or who transfer into the institution. This metric complies with the requirements of the federal Student Right to Know Act that requires institutions to report the completion status at $150 \%$ of normal time (or six years). Success Rate measures the percentage of an initial cohort of students who have either graduated or are still enrolled at the same university. This data should match the IPEDS Graduation Rate Survey data that is due in late February. 


\section{Section 4 - Undergraduate Education (continued)}

TABLE 4D. Graduation Rates for First-Time-in-College (FTIC) Students (includes Full- and Part-time students)

\begin{tabular}{lccccc}
$\mathbf{4 - Y e a r}$ Rates & $\mathbf{2 0 0 7 - 1 1}$ & $\mathbf{2 0 0 8 - 1 2}$ & $\mathbf{2 0 0 9 - 1 3}$ & $\mathbf{2 0 1 0 - 1 4}$ & $\mathbf{2 0 1 1 - 1 5}$ \\
\hline Cohort Size & 244 & 392 & 494 & 479 & 589 \\
Same University & $\mathbf{2 1 \%}$ & $\mathbf{1 7 \%}$ & $\mathbf{2 3 \%}$ & $\mathbf{2 1 \%}$ & $\mathbf{2 1 \%}$ \\
\hline Other USF institution & $9 \%$ & $10 \%$ & $11 \%$ & $9 \%$ & $12 \%$ \\
\hline Other University in SUS & $10 \%$ & $13 \%$ & $13 \%$ & $11 \%$ & $15 \%$ \\
\hline Total from System & $31 \%$ & $30 \%$ & $36 \%$ & $32 \%$ & $36 \%$
\end{tabular}

\begin{tabular}{lccccc}
$\mathbf{6 - \text { Year Rates }}$ & $\mathbf{2 0 0 5 - 1 1}$ & $\mathbf{2 0 0 6 - 1 2}$ & $\mathbf{2 0 0 7 - 1 3}$ & $\mathbf{2 0 0 8 - 1 4}$ & $\mathbf{2 0 0 9 - 1 5}$ \\
\hline \multicolumn{1}{c}{ Cohort Size } & 192 & 288 & 244 & 392 & 494 \\
Same University & $\mathbf{2 9 . 6 9 \%}$ & $\mathbf{3 1 . 6 0 \%}$ & $\mathbf{4 1 . 3 9 \%}$ & $\mathbf{3 1 . 6 3 \%}$ & $\mathbf{3 8 . 2 6 \%}$ \\
\hline Other USF institution & $14 \%$ & $17 \%$ & $21 \%$ & $21 \%$ & $22 \%$ \\
\hline Other University in SUS & $21 \%$ & $22 \%$ & $21 \%$ & $28 \%$ & $27 \%$ \\
\hline Total from System & $51 \%$ & $54 \%$ & $63 \%$ & $59 \%$ & $65 \%$
\end{tabular}

Notes: Cohorts are based on undergraduate students who enter the institution in the Fall term (or Summer term and continue into the Fall term). First-timein-college (FTIC) cohort is defined as undergraduates entering in fall term (or summer continuing to fall) with fewer than 12 hours earned after high school graduation. The initial cohorts can be revised to remove students, who have allowable exclusions as defined by IPEDS, from the cohort. FTIC students who are enrolled in advanced graduate degree programs that do not award a Bachelor's degree are removed from the cohorts.

Graduates are students in the cohort who have graduated by the summer term in their fourth or sixth year. Degree data often includes 'late degrees' which are degrees that were awarded in a previous term, but reported to SUDS later; so, the most recent year of data in this table only provides preliminary graduation rate data that may change with the addition of "late degrees". Late degrees reported in conjunction with the IPEDS Graduation Rate Survey due in mid-February will be reflected in the following year.

Same University provides graduation rates for students in the cohort who graduated from the same institution.

Other University in SUS provides graduation rates for students in the cohort who graduated from a different State University System of Florida institution. These data do not report students in the cohort who did not graduate from the SUS, but did graduate from another institution outside the State University System of Florida. 


\section{Section 4 - Undergraduate Education (continued)}

\section{TABLE 4E. Graduation Rates for AA Transfer Students from Florida College System}

\begin{tabular}{cccccc} 
Two - Year Rates & $\mathbf{2 0 0 9 - 1 1}$ & $\mathbf{2 0 1 0 - 1 2}$ & $\mathbf{2 0 1 1 - 1 3}$ & $\mathbf{2 0 1 2 - 1 4}$ & $\mathbf{2 0 1 3 - 1 5}$ \\
\hline Cohort Size & 289 & 269 & 345 & 341 & 351 \\
Same University & $22 \%$ & $23 \%$ & $22 \%$ & $25 \%$ & $21 \%$
\end{tabular}

\begin{tabular}{cccccc} 
Four - Year Rates & $\mathbf{2 0 0 7 - 1 1}$ & $\mathbf{2 0 0 8 - 1 2}$ & $\mathbf{2 0 0 9 - 1 3}$ & $\mathbf{2 0 1 0 - 1 4}$ & $\mathbf{2 0 1 1 - 1 5}$ \\
\hline Cohort Size & 272 & 295 & 289 & 269 & 345 \\
Same University & $57 \%$ & $55 \%$ & $58 \%$ & $64 \%$ & $52 \%$
\end{tabular}

Notes: AA Transfer cohort is defined as undergraduates entering in the fall term (or summer continuing to fall) and having earned an AA degree from an institution in the Florida College System. For comparability with FTIC cohorts, AA Transfer cohorts are based on undergraduate students who enter the institution in the Fall term (or Summer term and continue into the Fall term) and graduate from the same institution within two or four years.

\section{TABLE 4F. Graduation Rates for Other Transfer Students}

\begin{tabular}{rccccc}
$\mathbf{5}-$ Year Rates & $\mathbf{2 0 0 6 - 1 1}$ & $\mathbf{2 0 0 7 - 1 2}$ & $\mathbf{2 0 0 8 - 1 3}$ & $\mathbf{2 0 0 9 - 1 4}$ & $\mathbf{2 0 1 0 - 1 5}$ \\
\hline Cohort Size & 278 & 284 & 229 & 277 & 348 \\
Same University & $53 \%$ & $57 \%$ & $48 \%$ & $52 \%$ & $50 \%$
\end{tabular}

Notes: Other Transfer Students includes undergraduate students that transfer into a university who are not FTICs or AA Transfers. Cohorts are based on undergraduate students who enter the institution in the Fall term (or Summer term and continue into the Fall term) and graduate from the same institution within five years. 


\section{Section 4 - Undergraduate Education (continued)} TABLE 4G. Baccalaureate Degrees Awarded

\begin{tabular}{lccccc} 
& $\mathbf{2 0 1 0 - 1 1}$ & $\mathbf{2 0 1 1 - 1 2}$ & $\mathbf{2 0 1 2 - 1 3}$ & $\mathbf{2 0 1 3 - 1 4}$ & $\mathbf{2 0 1 4 - 1 5}$ \\
\hline First Majors & 687 & 706 & 826 & 821 & 825 \\
Second Majors & 18 & 30 & 20 & 25 & 17 \\
\hline TOTAL & 705 & 736 & $\mathbf{8 4 6}$ & $\mathbf{8 4 6}$ & $\mathbf{8 4 2}$
\end{tabular}

Note: This table reports the number of degrees awarded by academic year. First Majors include the most common scenario of one student earning one degree in one Classification of Instructional Programs (CIP) code. In those cases where a student earns a baccalaureate degree under two different degree CIPs, a distinction is made between "dual degrees" and "dual majors." Also included in first majors are "dual degrees" which are counted as separate degrees (e.g., counted twice). In these cases, both degree CIPs receive a "degree fraction" of 1.0. Second Majors include all dual/second majors (e.g., degree CIP receive a degree fraction that is less than 1). The calculation of degree fractions is made according to each institution's criteria. The calculation for the number of second majors rounds each degree CIP's fraction of a degree up to 1 and then sums the total. Second Majors are typically used when providing degree information by discipline/CIP, to better conveys the number of graduates who have specific skill sets associated with each discipline.

\section{TABLE 4H. Baccalaureate Degrees in Programs of Strategic Emphasis (PSE)} [Includes Second Majors]

2010-11

49

2011-12

2012-13

2013-14

63

69

2014-15

STEM

HEALTH

0

0

2

0

0

61

56

104

135

185

130

185

240

280

$34.04 \%$

$38.04 \%$

PSE PERCENT OF TOTAL

$34.04 \%$

Notes: This is a count of baccalaureate majors for specific Programs of Strategic Emphasis, as determined by the Board of Governors staff with consultation with business and industry groups and input from universities. This is a count of baccalaureate degrees awarded within specific Programs of Strategic Emphasis, as determined by the Board of Governors staff with consultation with business and industry groups and input from universities - for more information see: http://www.flbog.edu/pressroom/strategic_emphasis/. The Board of Governors revised the list of Programs of Strategic Emphasis in November 2013, and the new categories were applied to the historical degrees. A student who has multiple majors in the subset of targeted Classification of Instruction Program codes will be counted twice (i.e., double-majors are included). 


\section{Section 4 - Undergraduate Education (continued)}

TABLE 4I. Baccalaureate Degrees Awarded to Underrepresented Groups

2010-11 2011-12 2012-13 2013-14 2014-15

Non-Hispanic Black

$\begin{array}{lccccc}\text { Number of Degrees } & 24 & 36 & 53 & 41 & 42 \\ \text { Percentage of Degrees } & 4 \% & 5 \% & 7 \% & 5 \% & 5 \%\end{array}$

Hispanic

$\begin{array}{lccccc}\text { Number of Degrees } & 72 & 64 & 83 & 93 & 103 \\ \text { Percentage of Degrees } & 11 \% & 9 \% & 10 \% & 12 \% & 13 \%\end{array}$

Pell-Grant Recipients

$\begin{array}{lccccc}\text { Number of Degrees } & 276 & 333 & 417 & 438 & 477 \\ \text { Percentage of Degrees } & 40 \% & 46 \% & 51 \% & 54 \% & 58 \%\end{array}$

Note: Non-Hispanic Black and Hispanic do not include students classified as Non-Resident Alien or students with a missing race code. Students who earn two distinct degrees in the same term are counted twice - whether their degrees are from the same six-digit CIP code or different CIP codes. Students who earn only one degree are counted once - even if they completed multiple majors or tracks. Percentage of Degrees is based on the number of baccalaureate degrees awarded to non-Hispanic Black and Hispanic students divided by the total degrees awarded - excluding those awarded to non-resident aliens and unreported.

Pell-Grant recipients are defined as those students who have received a Pell grant from any SUS Institution within six years of graduation - excluding those awarded to non-resident aliens, who are only eligible for Pell grants in special circumstances. Percentage of Degrees is based on the number of baccalaureate degrees awarded to Pell recipients, as shown above, divided by the total degrees awarded - excluding those awarded to non-resident aliens.

Notes on Trends: In 2007, the US Department of Education re-classified the taxonomy for self-reported race/ethnicity categories and allowed universities a two-year phase-in process before all institutions were required to report based on the new categories for the 2011-12 academic year. This reclassification will impact trends. 


\section{Section 4 - Undergraduate Education (continued)}

\section{TABLE 4J. Baccalaureate Degrees Without Excess Credit Hours}

\begin{tabular}{|c|c|c|c|c|c|}
\hline & $2010-11$ & $2011-12$ & $2012-13^{*}$ & 2013-14 & 2014-15 \\
\hline FTIC & \multirow{4}{*}{$\begin{array}{c}\text { Data reported } \\
\text { at the System } \\
\text { Level }\end{array}$} & $67 \%$ & $64 \%$ & $75 \%$ & $75 \%$ \\
\hline AA Transfers & & $61 \%$ & $70 \%$ & $70 \%$ & $76 \%$ \\
\hline Other Transfers & & $37 \%$ & $56 \%$ & $60 \%$ & $55 \%$ \\
\hline TOTAL & & $55 \%$ & $64.18 \%$ & $67.94 \%$ & $69.40 \%$ \\
\hline
\end{tabular}

Notes: This table is based on statute 1009.286 (see link), and excludes certain types of student credits (e.g., accelerated mechanisms, remedial coursework, non-native credit hours that are not used toward the degree, non-native credit hours from failed, incomplete, withdrawn, or repeated courses, credit hours from internship programs, credit hours up to 10 foreign language credit hours for transfer students in Florida, and credit hours earned in military science courses that are part of the Reserve Officers' Training Corps (ROTC) program). This metric is not the same as the Excess Hours Surcharge, which has multiple cohorts with varying fee rates. This table reports the percentage of baccalaureate degrees awarded within $110 \%$ of the catalog hours required for a degree based on the Board of Governors Academic Program Inventory. This calculation is based on Hours To Degree data submitted by universities to the Board of Governors and excludes recent graduates who have already earned a baccalaureate degree. Note*: Improvements were made to data collection process beginning with 2012-13 data to better account for high school dual enrolled credits that are exempt from the excess hour calculation. Also, 2012-13 data marked a slight methodological change in how the data is calculated. Each CIP code's required number of 'catalog hours' was switched to the officially approved hours as reported within the Board of Governors' Academic Program Inventory - instead of the catalog hours reported by the university on the HTD files.

\section{TABLE 4K. Undergraduate Course Offerings}

$\begin{array}{cccccc} & \text { Fall 2010 } & \text { Fall 2011 } & \text { Fall 2012 } & \text { Fall 2013 } & \text { Fall 2014 } \\ \begin{array}{c}\text { Number of } \\ \text { Course Sections }\end{array} & 330 & 355 & 372 & 357 & 378\end{array}$

\section{Percentage of Undergraduate Course Sections by Class Size}

\begin{tabular}{lccccc}
\hline Fewer than 30 Students & $48 \%$ & $50 \%$ & $57 \%$ & $60 \%$ & $65 \%$ \\
\hline 30 to 49 Students & $43 \%$ & $42 \%$ & $34 \%$ & $30 \%$ & $26 \%$ \\
\hline 50 to 99 Students & $8 \%$ & $8 \%$ & $9 \%$ & $10 \%$ & $8 \%$ \\
\hline 100 or More Students & $0 \%$ & $0 \%$ & $1 \%$ & $1 \%$ & $0 \%$
\end{tabular}

Notes: This data is based on Common Data Set (CDS) definitions. According to CDS, a "class section is an organized course offered for credit, identified by discipline and number, meeting at a stated time or times in a classroom or similar setting, and not a subsection such as a laboratory or discussion session. Undergraduate class sections are defined as any sections in which at least one degree-seeking undergraduate student is enrolled for credit. Exclude distance learning classes and noncredit classes and individual instruction such as dissertation or thesis research, music instruction, or one-to-one readings. Exclude students in independent study, co-operative programs, internships, foreign language taped tutor sessions, practicums, and all students in one-on-one classes. 


\section{Section 4 - Undergraduate Education (continued)}

TABLE 4L. Percentage of Undergraduate Credit Hours Taught by Instructor Type

\begin{tabular}{lccccc} 
& $\mathbf{2 0 1 0 - 1 1}$ & $\mathbf{2 0 1 1 - 1 2}$ & $\mathbf{2 0 1 2 - 1 3}$ & $\mathbf{2 0 1 3 - 1 4}$ & $\mathbf{2 0 1 4 - 1 5}$ \\
\hline Faculty & $71 \%$ & $65 \%$ & $63 \%$ & $63 \%$ & $61 \%$ \\
\hline Adjunct Faculty & $28 \%$ & $35 \%$ & $36 \%$ & $36 \%$ & $37 \%$ \\
\hline Graduate Students & $0 \%$ & $0 \%$ & $0 \%$ & $0 \%$ & $0 \%$ \\
\hline Other Instructors & $1 \%$ & $0 \%$ & $0 \%$ & $1 \%$ & $2 \%$
\end{tabular}

Note: The total number of undergraduate state fundable credit hours taught will be divided by the undergraduate credit hours taught by each instructor type to create a distribution of the percentage taught by each instructor type. Four instructor types are defined as faculty (pay plans 01,02 , and 22), OPS faculty (pay plan 06), graduate student instructors (pay plan 05), and others (all other pay plans). If a course has more than one instructor, then the university's reported allocation of section effort will determine the allocation of the course's total credit hours to each instructor. The definition of faculty varies for Tables $4 \mathrm{~L}, 4 \mathrm{M}$ and $4 \mathrm{~N}$. For Faculty Teaching Undergraduates, the definition of faculty is based on pay plans 01,02 , and 22.

\section{TABLE 4M. Student/Faculty Ratio}

\begin{tabular}{ccccc} 
Fall 2010 & Fall 2011 & Fall 2012 & Fall 2013 & Fall 2014 \\
\hline Ratio & 19 & 22 & 22 & 22 \\
Note: This data is based on Common Data Set (CDS) definitions. This is the Fall ratio of full-time equivalent students (full-time plus $1 / 3$ part time) to full-time \\
equivalent instructional faculty (full time plus $1 / 3$ part time). The ratio calculations exclude both faculty and students in stand-alone graduate or professional \\
programs such as medicine, law, veterinary, dentistry, social work, business, or public health in which faculty teach virtually only graduate-level students. \\
Undergraduate or graduate student teaching assistants are not counted as faculty.
\end{tabular}




\title{
Section 4 - Undergraduate Education (continued)
}

\author{
TABLE 40. Post-Graduation Metrics
}

\section{Percent of Bachelor's Graduates Employed Full-time or Continuing their Education, One Year After Graduation}

\begin{tabular}{lcccc} 
& $\mathbf{2 0 1 0 - 1 1}$ & $\mathbf{2 0 1 1 - 1 2}$ & $\mathbf{2 0 1 2 - 1 3}$ & $\mathbf{2 0 1 3 - 1 4}$ \\
\hline Enrolled or Employed (Full-time) & $69.11 \%$ & $71.67 \%$ & $73.05 \%$ & $76.93 \%$ \\
Enrolled or Employed (Earned \$25,000+) &. &. & $61.10 \%$ & $67.12 \%$ \\
Number of States included in Search & 1 & 36 & 38 & 38 \\
Percent Found & $91 \%$ & $89 \%$ & $92 \%$ & $92 \%$
\end{tabular}

Notes: Enrolled or Employed Full-Time is based on the number of recent baccalaureate graduates who are either employed full-time or continuing their education within one year after graduation. Full-time employment is based on those who earned at least as much as a full-time (40hrs a week) worker making minimum wage. Enrolled or Employed (Earning \$25,000+) is based on the number of recent baccalaureate graduates who are either employed and earned at least $\$ 25,000$ or continuing their education within one year after graduation. The employed data includes non-Florida data that is available from the Wage Record Interchange System 2 (known as "WRIS 2") and Federal employee data that is available from the Federal Employment Data Exchange System (FEDES) initiative. Military employment data was collected by the Board of Governors staff from university staff. Due to limitations in the data, the continuing enrollment data includes any enrollment the following year regardless of whether the enrollment was post-baccalaureate or not. Percent Found refers to the percentage of graduates found in the dataset - including those that did not earn wages above the full-time threshold and those who were found outside of the one-year window.

For more information about the methodology see: http://www.flbog.edu/about/budget/performance_funding.php.

For more information about WRIS2 see: http://www.doleta.gov/performance/wris 2.cfm.

For more information about FEDES see: http://www.ubalt.edu/fif/fedes/.

\section{Median Wages of Bachelor's Graduates Employed Full-time in Florida, One Year After Graduation}

\begin{tabular}{lcccc} 
& $\mathbf{2 0 1 0 - 1 1}$ & $\mathbf{2 0 1 1 - 1 2}$ & $\mathbf{2 0 1 2 - 1 3}$ & $\mathbf{2 0 1 3 - 1 4}$ \\
\hline 5th PERCENTILE WAGE & $\$ 18,600$ & $\$ 19,000$ & $\$ 18,800$ & $\$ 18,400$ \\
\hline 25th PERCENTILE WAGE & $\$ 25,800$ & $\$ 26,000$ & $\$ 26,000$ & $\$ 27,300$ \\
\hline MEDIAN WAGE & $\$ 33,000$ & $\$ 34,900$ & $\$ 34,800$ & $\$ 35,400$ \\
\hline 75th PERCENTILE WAGE & $\$ 45,300$ & $\$ 43,600$ & $\$ 46,400$ & $\$ 45,000$ \\
\hline 95th PERCENTILE WAGE & $\$ 62,100$ & $\$ 64,000$ & $\$ 66,500$ & $\$ 67,000$ \\
\hline Percent Found & $56 \%$ & $60 \%$ & $61 \%$ & $62 \%$
\end{tabular}

Notes: Median Wage data is based on Florida's annualized Unemployment Insurance (UI) wage data for those graduates who earned at least as much as a full-time employee making minimum wage in the fiscal quarter a full year after graduation. This $\mathrm{UI}$ wage data does not include individuals who are selfemployed, employed out of state, employed by the military or federal government, or those without a valid social security number. This wage data includes graduates who were both employed and enrolled. Wages rounded to nearest hundreds. Percent Found refers to the percentage of graduates found in the dataset - including those that did not earn wages above the full-time threshold and those who were found outside of the one-year window. 


\section{Section 5 - Graduate Education}

\section{TABLE 5A. Graduate Degree Program Changes in AY 2014-15}

\begin{tabular}{|l|l|l|l|l|l|l|}
\hline \multicolumn{1}{|c|}{ Title of Program } & $\begin{array}{c}\text { Six-digit } \\
\text { CIP } \\
\text { Code }\end{array}$ & $\begin{array}{c}\text { Degree } \\
\text { Level }\end{array}$ & $\begin{array}{c}\text { Date of } \\
\text { UBOT } \\
\text { Action }\end{array}$ & $\begin{array}{c}\text { Starting } \\
\text { or Ending } \\
\text { Term }\end{array}$ & $\begin{array}{c}\text { Date of } \\
\text { Board of } \\
\text { Governors } \\
\text { Action }\end{array}$ & Comments \\
\hline New Programs & 52.0301 & Masters & $9 / 5 / 2014$ & $\begin{array}{l}2015 \\
\text { SPRING }\end{array}$ & & \\
\hline Accountancy & & & & & & \\
\hline & & & & & & \\
\hline & & & & & & \\
\hline Terminated Programs & & & & & \\
\hline \\
\hline \multicolumn{7}{|l|}{} \\
\hline
\end{tabular}

Note: This table does not include new majors or concentrations added under an existing degree program CIP Code. This table reports the new and terminated program changes based on Board action dates between May 5, 2014 and May 4, 2015.

New Programs are proposed new degree programs that have been completely through the approval process at the university and, if appropriate, the Board of Governors. Does not include new majors or concentrations added under an existing degree program CIP Code.

Terminated Programs are degree programs for which the entire CIP Code has been terminated and removed from the university's inventory of degree programs. Does not include majors or concentrations terminated under an existing degree program CIP Code if the code is to remain active on the academic degree inventory.

Programs Suspended for New Enrollments are degree programs for which enrollments have been temporarily suspended for the entire CIP Code, but the program CIP Code has not been terminated. Does not include majors or concentrations suspended under an existing degree program CIP Code if the code is to remain active on the academic degree inventory and new enrollments in any active major will be reported. Programs included in this list may have been suspended for new enrollments sometime in the past and have continued to be suspended at least one term of this academic year.

New Programs Considered by University But Not Approved includes any programs considered by the university board of trustees, or any committee of the board, but not approved for implementation. Also include any programs that were returned prior to board consideration by the university administration for additional development, significant revisions, or re-conceptualization; regardless of whether the proposal was eventually taken to the university board for approval. Count the returns once per program, not multiple times the proposal was returned for revisions, unless there is a total re-conceptualization that brings forward a substantially different program in a different CIP Code. 
Section 5 - Graduate Education (continued)

TABLE 5B. Graduate Degrees Awarded

\begin{tabular}{lccccc} 
& $\mathbf{2 0 1 0 - 1 1}$ & $\mathbf{2 0 1 1 - 1 2}$ & $\mathbf{2 0 1 2 - 1 3}$ & $\mathbf{2 0 1 3 - 1 4}$ & $\mathbf{2 0 1 4 - 1 5}$ \\
\hline First Majors & 144 & 146 & 143 & 167 & 222 \\
Second majors & 0 & 0 & 0 & 0 & 0 \\
\hline TOTAL & 144 & 146 & 143 & 167 & $\mathbf{2 2 2}$ \\
\hline Masters and Specialist (first majors) & 144 & 146 & 143 & 167 & 222 \\
Research Doctoral (first majors) & 0 & 0 & 0 & 0 & 0 \\
Professional Doctoral (first majors) & 0 & 0 & 0 & 0 & 0 \\
\hline Dentistry & 0 & 0 & 0 & 0 & 0 \\
Law & 0 & 0 & 0 & 0 & 0 \\
Medicine & 0 & 0 & 0 & 0 & 0 \\
\hline Nursing Practice & 0 & 0 & 0 & 0 & 0 \\
Pharmacy & 0 & 0 & 0 & 0 & 0 \\
Physical Therapist & 0 & 0 & 0 & 0 & 0 \\
\hline Veterinary Medicine & 0 & 0 & 0 & 0 & 0 \\
Other Professional Doctorate & 0 & 0 & 0 & 0 & 0
\end{tabular}

Note: This table reports the total number of graduate level degrees that were awarded by academic year as well as the number by level. The table provides a breakout for the Professional Doctoral degrees.

\section{TABLE 5C. Graduate Degrees Awarded in Areas of Strategic Emphasis}

[Includes Second Majors]

\begin{tabular}{lccccc} 
& $\mathbf{2 0 1 0 - 1 1}$ & $\mathbf{2 0 1 1 - 1 2}$ & $\mathbf{2 0 1 2 - 1 3}$ & $\mathbf{2 0 1 3 - 1 4}$ & $\mathbf{2 0 1 4 - 1 5}$ \\
\hline STEM & 10 & 6 & 8 & 3 & 3 \\
HEALTH & 0 & 0 & 0 & 0 & 0 \\
\hline GLOBALIZATION & 0 & 0 & 0 & 0 & 0 \\
\hline EDUCATION & 47 & 45 & 43 & 53 & 63 \\
\hline GAP ANALYSIS & 0 & 0 & 0 & 0 & 0 \\
\hline SUBTOTAL & 57 & 51 & 51 & 56 & 66 \\
\hline PSE PERCENT OF TOTAL & $39.58 \%$ & $\mathbf{3 4 . 9 3 \%}$ & $\mathbf{3 5 . 6 6 \%}$ & $\mathbf{3 3 . 5 3 \%}$ & $\mathbf{2 9 . 7 3 \%}$
\end{tabular}

Notes: This is a count of graduate degrees awarded within specific Areas of Strategic Emphasis, as determined by the Board of Governors staff with consultation with business and industry groups and input from universities. This is a count of graduate degrees awarded within specific Programs of Strategic Emphasis, as determined by the Board of Governors staff with consultation with business and industry groups and input from universities - for more information see: http://www.flbog.edu/pressroom/strategic emphasis/. The Board of Governors revised the list of Programs of Strategic Emphasis in November 2013, and the new categories were applied to the historical degrees. A student who has multiple majors in the subset of targeted Classification of Instruction Program codes will be counted twice (i.e., double-majors are included). Note: The denominator used in the percentage includes second majors. 


\section{Section 6 - Research and Economic Development}

TABLE 6A. Research and Development

2009-10

2010-11

2011-12

2012-13

2013-14

\section{R\&D Expenditures}

Total (S\&E and non-S\&E)

$(\$ 1,000$ s)

$$
\$ 4,419
$$

$\$ 3,978$

$\$ 5,488$

$\$ 6,905$

$\$ 6,908$

Federally Funded

(\$1,000s)

$\$ 2,570$

$\$ 2,058$

$\$ 2,799$

$\$ 3,031$

$\$ 2,768$

Percent Funded

From External Sources

$61 \%$

$55 \%$

$59 \%$

$53 \%$

$46 \%$

Total R\&D Expenditures

Per Full-Time, Tenured,

Tenure-Earning Faculty Member (\$)

$\$ 51,988$

$\$ 49,725$

$\$ 66,120$

$\$ 83,193$

$\$ 80,326$

Notes: R\&D Expenditures are based on the National Science Foundation's annual Survey of R\&D Expenditures at Universities and Colleges (data include Science \& Engineering and non-Science \& Engineering awards). Percent Funded from External Sources is defined as funds from federal, private industry and other sources (non-state and non-institutional funds). Total R\&D expenditures are divided by fall, full-time tenured/tenure-track faculty as reported to IPEDS (FGCU includes both tenured/tenure-track and non-tenure/track faculty). The fall faculty year used will align with the beginning of the fiscal year (e.g., 2007 FY R\&D expenditures are divided by fall 2006 faculty). 